NBER WORKING PAPER SERIES

\title{
AFRICAN AMERICAN INTERGENERATIONAL ECONOMIC MOBILITY SINCE 1880
}

\author{
William J. Collins \\ Marianne H. Wanamaker \\ Working Paper 23395 \\ http://www.nber.org/papers/w23395 \\ NATIONAL BUREAU OF ECONOMIC RESEARCH \\ 1050 Massachusetts Avenue \\ Cambridge, MA 02138 \\ May 2017, Revised April 2021
}

NSF support (SES 1156085 and 1156057) is gratefully acknowledged, as are discussant comments from Jeff Biddle and Robert Margo; comments from conference participants at the Southern Economic Association, American Economic Association, and Economic History Association annual meetings; and comments from seminar participants at Auburn University, Florida State University, the Oxford-Warwick-LSE Workshop, Queen's University, Tulane University, University of Arizona, UCLA, UC-Merced, University of Colorado, University of Michigan, University of Pittsburgh and Carnegie Mellon University, and Vanderbilt University. Sharonda Adams, Lauren Bamonte, Ye Gu, Nick Holtkamp, Blane Kassa, Dinan Liang, Bryson Lype, Mason Reasner, Shea Sabin, Musa Subramaniam, and Jim Teal provided excellent research assistance. The Grey and Dornbush gifts at Vanderbilt University and Office of Research at the University of Tennessee have provided research support. Brant Callaway, Andrew GoodmanBacon, Laura Salisbury, Richard Sutch, Zach Ward, and Ariell Zimran provided helpful insights. The views expressed herein are those of the authors and do not necessarily reflect the views of the National Bureau of Economic Research.

NBER working papers are circulated for discussion and comment purposes. They have not been peer-reviewed or been subject to the review by the NBER Board of Directors that accompanies official NBER publications.

(C) 2017 by William J. Collins and Marianne H. Wanamaker. All rights reserved. Short sections of text, not to exceed two paragraphs, may be quoted without explicit permission provided that full credit, including $\odot$ notice, is given to the source. 
African American Intergenerational Economic Mobility Since 1880

William J. Collins and Marianne H. Wanamaker

NBER Working Paper No. 23395

May 2017, Revised April 2021

JEL No. J15,J62,N31,N32

\title{
ABSTRACT
}

We document the intergenerational mobility of black and white American men from 1880 through 2000 by building new historical datasets for the late nineteenth and early twentieth century and combining them with modern data to cover the middle and late twentieth century. We find large disparities in mobility, with white children having far better chances of escaping the bottom of the distribution than black children in every generation. This mobility gap was more important in proximately determining each generation's racial gap than was the initial gap in parents' economic status.

\author{
William J. Collins \\ Department of Economics \\ Vanderbilt University \\ VU Station B \#351819 \\ 2301 Vanderbilt Place \\ Nashville, TN 37235-1819 \\ and NBER \\ william.collins@vanderbilt.edu \\ Marianne H. Wanamaker \\ Department of Economics \\ University of Tennessee \\ 524 Stokely Management Center \\ Knoxville, TN 37996 \\ and NBER \\ wanamaker@utk.edu
}


In 1870, five years after the Civil War and Thirteenth Amendment abolished slavery in the United States, African Americans' income per capita was approximately 28 percent of whites' income (Margo 2016). By 2010, the black-white income ratio had risen to 64 percent, a convergence that remains incomplete and that has far-reaching social ramifications. This paper quantifies the role of intergenerational mobility in determining the relative economic status of black workers over more than 100 years, from the end of Reconstruction, when federal troops left the South, to the beginning of the twenty-first century. Specifically, for several cohorts of father-son pairs, we measure the extent to which black men's relatively poor labor market outcomes reflected their fathers' disadvantaged economic status as opposed to racial differences in outcomes conditional on fathers' status.

Our data encompass nearly the full span of economic and political change for black Americans since the Civil War, including the rise of discriminatory "Jim Crow" institutions, the Great Migration from the South, and the Civil Rights revolution and its aftermath. Developing an intergenerational perspective over the long run requires information that is simply unavailable in census microdata samples, which are the foundation for most studies of U.S. labor markets before the 1960s. To overcome the most binding limitations, we have built new intergenerational datasets by linking individuals' census records from 1880 to 1900, and again, for a different set of individuals, from 1910 to 1930. Linked census records are valuable in this early period because no other nationally representative datasets contain information on both parents' and children's labor market outcomes. ${ }^{1}$ For the post-1930 period, we use modern datasets with intergenerational information to complete the portrait of black men's economic mobility in comparison to whites. We rely on the Occupational Changes in a Generation data (OCG), which were collected in 1962 and 1973, and the National Longitudinal Survey of Youth 1979 data (NLSY79) (Bureau of Labor Statistics, 2019), which follow a young cohort from 1979 into adulthood.

Our main metrics of mobility compare each son's estimated position in the national earnings distribution to his father's position in the distribution two decades earlier. ${ }^{2}$ This rank-based approach follows Dahl and DeLeire (2008), Mazumder (2014), Davis and Mazumder (2018), and Chetty et al. (2014, 2020). It conforms to notions of "moving up" or "falling behind" relative to one's peers from generation to generation, and it dovetails with the economics literature's longstanding emphasis on

\footnotetext{
${ }^{1}$ See Ferrie (1996), Long and Ferrie (2013), Abramitzky, Boustan, and Eriksson (2014), and Feigenbaum (2018) for prominent examples of census record linkage. See Bailey et al. (2019) and Abramitzky et al (2019) for discussion of methodological issues. See Olivetti and Paserman (2015) for an approach to studying intergenerational mobility that relies on children's names rather than linked microdata.

${ }^{2}$ Studies using linked census records have focused on men because women's names changed at marriage.
} 
studying changes in black workers' relative status (Smith and Welch 1989, Donohue and Heckman 1991, and Margo 2016). Because the Census of Population did not collect income data before 1940, our measures of economic status are necessarily based on what we know about the men's occupation, race, and geography; this entails a detailed "earnings score" assignment process that we describe below.

In the absence of group-specific conditions that would curtail convergence, population-wide estimates of intergenerational income transmission in the modern literature would predict a fairly rapid narrowing of average income gaps between black and white workers (Margo 2016, p. 314). But, in fact, in each generation in our data, we find large racial differences in sons' economic status conditional on their fathers' economic status, suggesting that population-wide estimates of intergenerational mobility mask deep heterogeneity. In particular, the children of low-status white families have had much higher rates of upward mobility than similarly situated black children since 1880. Based on these data, we conclude that it was not only, or even primarily, initial income disparities per se that limited the pace of black workers' economic progress in the historical samples. Rather, our results show a sharp disadvantage for black men relative to white men in the likelihood of escaping the bottom ranks of the income distribution throughout US history. It is striking that in the historical samples (1880-1900 and 1910-30) children from the poorest white families could expect, on average, to be better off as adults than children from the best off black families. It is also striking that large black-white differences in economic status conditional on parents' status continued into the post-World War II era despite the Great Migration and Civil Rights legislation. This mobility gap was comparable in magnitude in 1973, nearly a decade after the Civil Rights Act, to what it was in 1900, at the height of Jim Crow institutions. We also find that the gap cannot be accounted for by differences in readily observable characteristics of families, such as region of residence or parents' educational attainment.

These differences in intergenerational mobility are empirically essential to understanding the history of racial disparities in US labor markets. In each generation that we observe, if black children had transitioned up or down the income distribution in the same way as white children with similarly situated parents, they would have greatly improved their average labor market outcomes relative to the actual course of history. In this sense, paraphrasing sociologist Otis Duncan (1968a), the inheritance of race rather than the inheritance of poverty has been the first-order determinant of racial disparities since emancipation.

Our work builds on and contributes to two closely related but distinct economics literatures. First, a burgeoning literature studies the transmission of labor market outcomes across generations 
(e.g., Becker and Tomes 1979, 1986; Solon 1992, 1999; Mazumder 2005; Black and Devereux 2011; Long and Ferrie 2013; Chetty et al. 2014; Olivetti and Paserman 2015). Within the intergenerational mobility literature, several studies investigate racial differences in intergenerational income mobility in recent decades (Hertz 2005, Isaacs 2008, Bhattacharya and Mazumder 2011, Mazumder 2014, Derenoncourt 2019, Chetty et al. 2020). Typically, they find substantial racial differences in mobility out of the lower end of the income distribution and in maintaining positions higher in the distribution. Second, a long-standing economics literature studies the evolution of black-white differences in average income and human capital. A number of important studies trace the convergence process far back into history, encountering many of the same data limitations that we confront in this paper (e.g., Higgs 1977, Smith 1984, Card and Krueger 1992, Sacerdote 2005, Margo 2016, Carruthers and Wanamaker 2017). In addition, there is a sizable literature on intergenerational mobility in sociology (Duncan 1968a,b, Featherman and Hauser 1976, Hout 1984, Sharkey 2013). Relative to these lines of research, our goal is to develop evidence that consistently measures the interaction of race, intergenerational mobility, and labor market outcomes over a long period of American history, covering a variety of institutional and policy regimes since the Civil War.

Our focus on the rank of individuals in the national income distribution, rather than their income per se, is borne of necessity but carries limitations. Most important, the income level represented by an income rank depends on the overall distribution of income. Recent evidence demonstrates that a constant income rank for black men could mask changes in relative income levels, as the income distribution compressed and fell at the lower end while stretching and growing at the upper end (Bayer and Charles 2018, Manduca 2018). And because the ranks we assign are based on occupation scores, they cannot capture variation in incomes within a particular occupationrace-geography combination. Our focus is on income ranks, with the understanding that they do not provide a complete picture of income levels and household welfare.

The implications of finding large differences in economic mobility over many generations and policy regimes are far reaching. First, although being from a better off family has been advantageous for both black and white children relative to others of the same race throughout the time period we study, it is important that narrowing the black-white gap in parental earnings in a single generation would still leave large gaps in expected income for children due to stark differences in mobility patterns. Thus, one-off transfers of income, in and of themselves, might not have made a large and lasting impression on the evolution of the black-white income gap because the groups tended to revert to different means. Deeper and more sustained economic, political, and social reform would have been required for black Americans to close the income gap permanently. Second, 
our results provide more evidence that the changes in institutions, policies, and racial animus that did take place over the past century, including the Civil Rights Movement, have not led to great improvements in the adult outcomes of black children relative to white children from households with similar economic characteristics. The persistence of this racial mobility gap calls for more research on its historical and contemporary causes and mechanisms, a topic we return to in the paper's conclusion.

\section{Background on Black-White Differences in Economic Status and Mobility}

\section{A. Historical Context}

In 1880, at the start of our period of study, the overwhelming majority of African Americans were former slaves or directly descended from slaves, and 92 percent lived in the South. ${ }^{3}$ Black men were primarily engaged in agriculture as farm laborers, sharecroppers, or tenant farmers, and most of the rest were unskilled non-farm laborers. Most were also illiterate because slaves had been forbidden from learning to read and write (Williams 2005). There was no widespread redistribution of property or compensation paid to former slaves in the wake of the Civil War, despite calls for "40 acres and a mule" (Oubre 1978). Thus, on average, black Americans were a relatively poor population and concentrated in a relatively poor region, as the South lagged behind the rest of the US (Engerman 1966, Margo 2004). The post-bellum South presented additional headwinds, including relatively high rates of incarceration, efforts to limit black laborers' mobility, and scarce credit (Myrdal 1944, Ransom and Sutch 1977, Woodman 1995, Hutchinson and Margo 2006, Naidu 2010).

In the late nineteenth and early twentieth century, black Americans did gain relative to whites in literacy, property ownership, and per capita income (Higgs 1977, 1982; Margo 1984, 1990, 2016), but they started from a very low base. Opportunities to acquire human capital were limited and unequal across races. Public schools, established in the South after the Civil War, were segregated, and racial gaps in school quality widened after 1880 (Margo 1990, Carruthers and Wanamaker 2017). This reflected whites' control over both local and state-allocated funding in the wake of widespread disenfranchisement of black voters (Kousser 1974, Klarman 2004). Although gaps in literacy narrowed sharply for cohorts born after the Civil War (Sacerdote 2005), it is likely that gaps in actual educational attainment widened for birth cohorts between 1880 and 1910 (Collins and Margo 2006), as white cohorts gained faster than black cohorts at the national level. In addition to

\footnotetext{
${ }^{3}$ It is not possible to ascertain from the from post-Civil War censuses whether someone had been a slave. In 1860, at the time of the last census before the Civil War, about 96 percent of the black population residing in the South were slaves (Ransom 2006), including Kentucky but not Maryland, Delaware, or Missouri.
} 
disparities in access to schooling, black workers were denied entry into many skilled occupations and new lines of work in southern manufacturing and services (Myrdal 1944, Ch. 13; Wright 1986, pp. 177-195).

Large-scale black migration to the North began during World War I, when northern employers began recruiting and hiring more black workers (Woodson 1918, Grossman 1989, Collins 1997, Boustan 2017). The "Great Migration" of southern-born black workers to cities in the North and West continued into the 1960s, and by 1970, approximately one-third of southern-born black adults had left the South. ${ }^{4}$ Although discrimination was common in non-southern labor markets (Myrdal 1944; Foote, Whatley, Wright 2003), the economic returns to black workers' inter-regional migration were substantial and contributed to some narrowing of the black-white income gap (Collins and Wanamaker 2014). Black men's relative wage gains were especially large in the 1940s, as migration from the South surged and the US income distribution compressed (Maloney 1994, Margo 1995). During this long period of mass migration and urbanization, measures of residential segregation increased throughout the US (Cutler, Glaeser, and Vigdor 1999; Logan and Parman 2017).

During the 1960s, the Civil Rights Movement transformed race relations in the South by dismantling de jure segregation and curbing discrimination in labor markets, voting, education, healthcare, and public accommodations (Wright 2013). Space does not allow a full recounting here, but the upshot was an increase in the black-white wage ratio during the 1960s (Freeman 1981, Donohue and Heckman 1991, Derenoncourt and Montialoux 2020, Aneja and Avenancio-Leon 2019). This momentum did not continue for black men past 1980, however, leading scholars to take up the question of "What went wrong?" (Bound and Freeman 1992).5 Bayer and Charles (2018, Figures IV and V) show that the median earnings gap between black and white men, including those out of the labor force, has widened since 1980, and, in 2010, was roughly equivalent to its value in 1950.

In sum, black-white income convergence since 1880 has been substantial but slow, with temporary accelerations in the 1940s and 1960s. Large racial gaps in men's labor market outcomes remain. In this paper, we seek to document and understand the role of differences in intergenerational mobility patterns in perpetuating this gap.

\footnotetext{
${ }^{4}$ Authors' calculations with 1970 Form 1 State one-percent sample from IPUMS (Ruggles et al. 2015), restricted to those age 18 and above.

${ }^{5}$ The time series for women's wages is different, showing more black-white convergence, but it is complicated by differences and changes in selection into the labor force (Neal 2004, Collins and Moody 2017).
} 


\section{B. Closely Related Work on Black-White Differences in Intergenerational Mobility}

As mentioned above, a relatively small number of empirical papers in economics study black-white differences in intergenerational economic mobility. Three that are close in spirit to our analysis are Hertz (2005), Mazumder (2014), and Chetty et al. (2020), which use panel datasets to characterize income mobility in recent decades, from the 1970s through $2015 .{ }^{6}$ They consistently find that black men were less likely than whites to move out of the bottom of the income distribution, conditional on starting at the bottom as children. Black men were also more likely than whites to fall out of the upper levels of the income distribution, conditional on starting there. ${ }^{7}$ Like this paper, these studies highlight the quantitative importance of differences in mobility patterns, as opposed to differences in parental income, in transmitting racial disparities over generations. Our paper's main contribution relative to this literature is to expand the scope of investigation, using panel data to cover cohorts from the first post-emancipation generations to the end of the twentieth century, and developing consistent comparative analyses over eras that had different institutional and economic environments. ${ }^{8}$

Empirical studies of intergenerational mobility attempt to hold parental income constant. But, of course, other resources that matter to human development might not be equalized. In particular, theoretical perspectives on race and intergenerational mobility highlight that even for children of parents with similar income and preferences, differences in social connections and community-level resources may affect human capital and subsequent labor market outcomes. Loury (1977, p. 157), describes human capital production as "a social process; that is, interactions of home, community, and an educational institution convert a young person's innate capabilities into marketable characteristics." Racial segregation and group differences in average economic status or human capital will distinguish the human capital accumulation of individuals with otherwise similar

\footnotetext{
${ }^{6}$ Hertz (2005) uses data from the Panel Study of Income Dynamics (PSID), which began in 1968. Mazumder (2014) uses data from the National Longitudinal Survey of Youth 1979 (NLSY79) and several waves of the Survey of Income and Program Participation (SIPP) matched to Social Security Administration earnings records. Chetty et al. (2020) combine income tax data and census records to study the intergenerational mobility of children born between 1978 and 1983. Hilger (2016) studies intergenerational educational mobility in census data from 1940 forward, finding evidence of increasing mobility for black and white southerners (i.e., flattening slopes of children's education relative to parents' education or income).

${ }^{7}$ Chetty et al. (2020) point out that the patterns for black women are fairly similar those for white women in recent decades, implying that the mobility gap is primarily due to differences in men's patterns.

${ }^{8}$ Darity et al. (2001), similar in spirit to Borjas (1994), use cross sectional data from the census to show that men from race and ethnic groups that had relatively large earnings score gaps circa 1880-1910 continued to have such gaps later in the century even after controlling for observables. In this way, the disadvantages of the past can be seen in modern cross sectional evidence.
} 
observables. In another example, Lundberg and Startz (1998) emphasize externalities in the production of human capital in which the productivity of human capital investment is increasing in the surrounding community's level of human capital. Thus (again), segregation and historical differences in groups' average human capital levels may have left black children at a disadvantage such that "the damage inflicted by past oppression can weigh indefinitely on future generations" (p. 320). Margo (2016) also features a framework in which "racial identity influences access to institutions and social networks complementary to human capital production" (p. 316). In addition, he points out that the geographic concentration of black families in areas with worse economic opportunities may have extended black children's disadvantage into the late twentieth century and beyond. ${ }^{9}$ All these frameworks feature mechanisms that perpetuate the mobility gap even in the absence of contemporary labor market discrimination, but none rules out the importance of such discrimination in practice.

There is also a large sociology literature on intergenerational mobility, some of which focuses on racial disparities and uses the same data that we examine for the mid-twentieth century. Duncan (1968b) studies racial differences in the first wave of the OCG dataset for men observed in 1962. A key conclusion is that "[a]lthough Negro social origins [occupations of fathers] are not as favorable as those of whites, this is the lesser part of the explanation of racial differences in occupation achievement. The greater part of the explanation lies in the inequalities within the process of mobility itself' (p. 11, emphasis added). ${ }^{10}$ Our data and methods allow us to expand the scope of investigation forwards and backwards in time relative to the mid-century OCG samples, providing a longer-run perspective on black-white differences in intergenerational mobility. In more recent work, Sharkey (2013) develops evidence from the Panel Study of Income Dynamics (PSID) to argue that childhood neighborhoods are an important intergenerational conduit for black-white

\footnotetext{
${ }^{9}$ Margo's reference to "spatial mismatch" includes both concentration in the South, a relatively low-wage region for much of US history, and later, concentration in central-city neighborhoods as jobs relocated to suburban areas (see Kain 1968, Wilson 1987). His reference to "bad ghettos" refers to the negative correlation between the level of residential segregation and black labor market outcomes, which strengthens after 1970 (Cutler and Glaeser 1997, Collins and Margo 2000). Though not focused on racial disparities, Tan (2019) emphasizes the importance of local labor markets for intergenerational mobility in the early twentieth century in contrast to the emphasis on childhood environment in more recent decades.

${ }^{10}$ Featherman and Hauser (1976) and Hout (1984) also study racial differences in the OCG data, including the second wave of the survey taken in 1973. Featherman and Hauser find gains in average occupational status for black men observed in 1973 relative to their fathers (measured by Duncan's socioeconomic index), whereas the cohort of black men observed in 1962 had only small intergenerational gains. Their interpretation emphasizes improvements in black men's educational attainment and labor market returns to education between the survey dates. Hout (1984) finds that the black men who experienced occupational upgrades during the 1960s tended to come from better off backgrounds in terms of their fathers' occupations.
} 
inequality. This line of research is focused on the post-1960 period and draws on Wilson (1987), who argues that deindustrialization intensified poverty in central-city black neighborhoods in the 1970s and 1980s; Massey and Denton (1993), who argue that high levels of residential segregation exacerbated the effects of deteriorating labor markets; and Pattillo-McCoy (1999), who shows how growing up in a predominantly middle-class black neighborhood may not effectively insulate black youth from the perils of downward mobility.

\section{Data and Measurement}

\section{A. Historical and Modern Datasets for Studying Economic Mobility}

We have built new datasets of linked census records that cover one set of father-son pairs observed in 1880 (providing the father's labor market outcome) and 1900 (for the son's outcome) and a second set of father-son pairs observed in 1910 and 1930. Since these datasets are new, we introduce them here at some length and describe them in more detail in the data appendix (Appendix I) and refer readers to the data deposit for replication files (Collins and Wanamaker, 2021). The modern datasets that we use to complete the long-run portrait of mobility, the OCG surveys for 1962 and 1973 (Blau et al. 1999) and the NLSY79, are more familiar to scholars. We spend less space on their basic description here, but we highlight some issues of comparability between the historical and modern samples.

To build the 1880 to 1900 linked dataset, we started with the full count files of the 1880 Census of Population (Minnesota Population Center 2017). We limited the sample to black and white males born in the United States, aged 0 to 17 with their father or stepfather present in the household. ${ }^{11}$ We searched for the sons two decades later in the full count files of the 1900 Census of Population, based on state of birth, age, race, sex, and first and last name. We followed a similar process for the 1910 to 1930 period. $^{12}$

Our linking method follows a recommendation from Bailey et al. (2020) by taking the intersection of links made by two well defined and widely used approaches, which are described in detail in Appendix I. The first is a variant of Ferrie's method (1996), based on code provided by Bailey and Cole (2019). The second is a variant of Abramitzky, Boustan, and Eriksson's method (2014). Taking the intersection of links should improve match quality by ensuring the uniqueness of

\footnotetext{
${ }^{11}$ Thirteen percent of sons in the sample are dropped because of missing fathers in 1880; nine percent are dropped for this reason in 1910.

12 The source for 1900, 1910, and 1930 complete count databases, with names, is Ruggles et al. 2015. All three were accessed through the NBER. See Collins and Wanamaker (2021) for version and other details.
} 
matches based on multiple criteria. Potentially unreliable matches from one method might be weeded out by the other method. A predictable tradeoff in using the intersection strategy is that match rates are low in comparison to studies that use only one approach (approximately 9 percent for 1880-1900 and 12 percent for 1910-30), but the sheer size of the complete count datasets results in linked datasets that are also fairly large. ${ }^{13}$ To account for selection into the linked sample, we weight the sample based on inverse probability of linkage; this is based on a probit model of successful matches using characteristics of sons in the initial year $(1880,1910)$. Key summary statistics of the weighted analysis sample resemble those in the IPUMS samples from which the matches are made.

Many of the fathers in the 1880-based dataset were farmers, but the 1880 Census of Population does not provide information to differentiate their economic status, apart from race and location. Farm ownership was a major distinction in economic and legal status at the time and is a distinction we can also make in 1900, 1910, and 1930 by relying on the Census of Population's home ownership question. ${ }^{14}$ To learn more about farmers in 1880, we conducted a second linking exercise to locate a random subsample of the linked Census of Population records in the farm-level manuscripts of the 1880 Census of Agriculture. We searched Ancestry.com (2020 for approximately 14,000 farmers "by hand" and located approximately 74 percent of them (both white and black). ${ }^{15}$ We then transcribed information about their farms from the manuscripts, focusing on whether the farmer owned the farm. An unfortunate drawback is that a limited number of states' agricultural census manuscripts are searchable online. The "searchable" states include approximately 57.5 percent of all male farmers (58.2 percent of black farmers) in 1880. The farm ownership rate in the

\footnotetext{
${ }^{13}$ We match 1,959,000 father-son pairs between 1910 and 1930 and 913,860 between 1880 and 1900. The difference in sample sizes reflects a growing population of 0 to 17 year olds between 1880 and 1910 and a higher match rate in the 1910-1930 sample. The working sample in both years is smaller as a result of missing data on occupation for fathers or sons and the farmer matching procedure for 1880 described below.

${ }^{14}$ Of course, some farmers did not own their home but did own the land they farmed, and vice versa. Still, we find a close correspondence between rates of home ownership in the 1920 Census of Population and rates of farm ownership in the 1920 Census of Agriculture (as reported in Goldenweiser and Truesdell 1924, p. 53). Goldenweiser and Truesdell report that 38.1 percent of farmers were tenants (including croppers); we calculate that 39.1 percent were renters in the 1920 1-percent IPUMS sample. Collins and Margo (2011) similarly equate farm ownership with home ownership.

${ }^{15}$ There are several reasons we might not find a farmer in the Census of Agriculture manuscripts. Names could be enumerated or transcribed differently across the Census of Population and Census of Agriculture records; self-reported "farmers" in the Census of Population might not have been the sole operator of a farm (the Census of Agriculture lists only one); census enumerators might not have filled out a schedule for every farm (e.g., marginal farms could be missed) or the schedule might not have been preserved; or we might have simply not found a farmer who is actually in the manuscripts somewhere. Our search protocol is described in the Appendix I.a.iii. For sons of farmers in the 1880 cohort, the final analysis weights are the product of the probability weights that adjust for selection into linkage multiplied by the number of farmers in the linked sample divided by the number of farmers successfully matched to the agriculture census, separately by race.
} 
searchable states is similar to that in US as a whole (73.4 percent versus 74.4 percent), suggesting that the searchable states are fairly representative on this dimension. ${ }^{16}$ In addition, the ownership rate in "found" farms (from our search of manuscripts) is similar to that in published tables from the Census of Agriculture. Again, details are provided in Appendix I.

Some matched pairs are missing occupational data for fathers, sons, or both, either because no occupation was reported, or because the occupation coding procedure is incomplete in the full count files. ${ }^{17}$ In addition, farmers in 1880 (and their sons) who are not linked to the Census of Agriculture manuscripts (described above) are not part of the final linked sample. For 1880 to 1900, the working sample contains 282,980 white father-son pairs and 25,119 black father-son pairs; for 1910 to 1930 , the sample includes $1,415,312$ white father-son pairs and 82,223 black father-son pairs. ${ }^{18}$ Linked census data cannot be constructed for men in the second half of the twentieth century due to confidentially restrictions on the use of census manuscripts. Instead, we rely on modern datasets that contain intergenerational information spanning the middle to late twentieth century. The OCG data were originally compiled as supplements to the Current Population Surveys in 1962 and 1973 (Blau et al. 1999). They provide information on current labor market outcomes, as well as retrospective information about the father's (or household head's) occupation when the respondent was 16 years old. One advantage of the OCG dataset is its timing in 1962 and 1973, which provides a view of labor market outcomes just before and several years after landmark civil rights legislation.

Next, we use the NLSY79, which began with over 12,000 males and females who were age 14 to 22 in 1979. Respondents were interviewed each year until 1994 and then every other year. The NLSY79 data are similar to the OCG data in that they report the father's (or household head's) occupation when the respondent was 14 years old based on a retrospective question posed at the start of the survey. We focus on males for consistency with the earlier datasets. The data appendix (Appendix I) provides additional details on the OCG and NLSY79 samples.

Differences in data structure pose a challenge when comparing the historical samples to the OCG or NLSY data. Because most of our analyses compare black-white mobility within samples,

\footnotetext{
${ }^{16}$ States with searchable records are Alabama, California, Connecticut, Georgia, Illinois, Iowa, Kansas, Maine, Massachusetts, Michigan, Nebraska, New York, Ohio, South Carolina, Tennessee, Texas, Virginia, and Washington. The most notable lack of coverage is in the Mountain states, but only 0.9 percent of farmers were located there in 1880.

${ }^{17}$ Not all occupation strings have been coded in the underlying IPUMS data for 1900 and 1930 . We perform a supplemental occupation coding process to fill in some omitted values, as described in Appendix I.a.ii.

18 The 1880 numbers are substantially smaller because while all linked non-farmers are included, only the subset of farmers who are linked to their agricultural census record in 1880 can be included in the analysis sample. Successfully linked farmers are re-weighted to account for their smaller numbers.
} 
the incongruities across datasets are not a paramount concern, but we highlight the issues here for clarity. ${ }^{19}$ First, in the historical datasets, we see the sons in the labor market exactly 20 years after we see the fathers. But in the OCG and NLSY data, the reference is to the father's occupation when the son was 16 or 14 years old, which could be any number of years prior to the survey (e.g., for a 30year old respondent in the OCG survey, the question pertains to 14 years prior). There is no way to make the datasets perfectly comparable in this regard while retaining useful sample sizes, but we can see how sensitive results are to age restrictions for sons in the modern samples. (See Appendix IV for details.) For instance, an age range of 20-37 in the OCG is most directly comparable to the ages at which we see adult sons in the historical samples, but the range 28-44 (centered on 36) gets closer to the historical samples' 20-year difference between the observation of father's and son's occupation. ${ }^{20}$

A second issue relates to the reference parent. In the historical samples, approximately 90 percent of sons resided with fathers or stepfathers, and we base our analyses on this group. Because occupations are often not reported for female household heads in these censuses, it would be difficult to assign an income score. ${ }^{21}$ The OCG and NLSY79 surveys asked respondents about the adults with whom they resided at age 16 or 14, respectively, and about the adults' occupations at that juncture. We use these responses to assign income scores based on the father's occupation if the father was present and on the mother's occupation if the father was not present. Alternatively, Appendix IV includes a sensitivity check that uses an "other male head"-based score for those living with their mother and another adult male, which makes little difference to our results. A small number of individuals who resided with neither their mother nor father at age 16 or 14 are dropped from the analysis. ${ }^{22}$ For brevity, when we refer to "fathers" throughout the rest of this paper, we mean fathers or stepfathers in the historical samples, and we mean fathers or household-head mothers in the modern samples.

\section{B. Assigning Income Scores and Ranks}

In all of the intergenerational samples we examine, we can observe an individual's detailed occupation, race, region of residence, and gender. Our approach entails ranking men based on

\footnotetext{
${ }^{19}$ There is precedent for this exercise. Long and Ferrie (2013) compare a dataset of linked historical census records to the OCG data for 1973 in their characterization of US intergenerational mobility.

${ }^{20}$ We discuss a related concern about "life-cycle bias" below (Grawe 2006, Haider and Solon 2006).

${ }^{21}$ For instance, in 1910, more than 40 percent of female-headed households with children present (under age 18) do not have an occupation reported in the 1-percent IPUMS sample. See Goldin (1990, chapter 2 and its appendix) for discussion of how the census enumerated women's gainful employment before 1940 .

${ }^{22}$ This represents 3 percent of the sample in the 1962 OCG, 5 percent of the sample in the 1973 OCG, and 4 percent of the NLSY79 sample.
} 
income within the cells defined by these characteristics. We assign income scores based on the average earnings of individuals in the same occupation, race, region of residence, and gender cell, drawn from the decennial census with earnings information that is closest in time. This is similar in spirit to the often-used occscore variable from IPUMS (Ruggles et al. 2015), which is based on occupation-specific earnings in 1950. But the scoring used here has much more flexibility, reflecting recent evidence that more flexible scoring provides more reliable comparisons across groups (Inwood, Minns, and Summerfield 2019; Ward 2020; Saavedra and Twinam 2020). Income assignments that would be based on fewer than 50 underlying census observations are supplanted with scores based on a race- and occupation-specific national average (not region-specific) or, if necessary, based on a race-specific one-digit occupation (rather than the three-digit code). Later in the paper, we discuss robustness to using alternative methods of assigning occupational scores.

For fathers observed in 1880 and 1910 and for sons observed in 1900 and 1930, income score assignments are based primarily on wage and salary data from the full count files of the 1940 census. The size of the 1940 full count dataset is advantageous because it allows for the finely sliced occupation-race-region-gender cells mentioned above, and the timing is advantageous because it comes before the "great compression" of the 1940s wage distribution (Goldin and Margo 1992). Because the 1940 census did not collect information on self-employment income, we use withinoccupation ratios of mean earnings for self-employed workers relative to wage-and-salary workers from 1960 to impute earnings for self-employed non-farm workers in 1940.

In the historical samples, we allow income scores for farmers to vary by ownership status. Moreover, we account for non-wage farm income in the form of perquisites for all agriculture workers (both agricultural laborers and farmers), using information from the US Department of Agriculture (USDA) as described in Appendix I. ${ }^{23}$ Because farmers' self-employment income is not reported directly in the 1940 census, we assign an earnings score by assuming that the ratio of farmers' total compensation (including in-kind income) relative to farm laborers' total compensation was the same in 1940 as it was in 1960 (within race, region, and farm ownership cells). ${ }^{24}$

For an alternative scoring scheme, we have estimated farmers' income from published tables

\footnotetext{
${ }^{23}$ We use perquisite rates inferred from U.S. Department of Agriculture (1957) measures of cash wages and non-cash compensation. See Appendix I for a more detailed description.

${ }^{24}$ In 1960, one observes earnings for both farmers and farm laborers. This approach allows for changes in earnings between region and race cells between 1940 and 1960 (as reflected in laborers' earnings), but it does not allow for differential changes in farmer versus farm laborer earnings. This approach relies on earnings information from the Census of Population, where the unit of observation is the worker. This is relevant because self-reported farmers may earn income in ways other than operating their own farm. Information from the Census of Agriculture, on the other than, is farm-level.
} 
in the 1900 Census of Agriculture on farm-level production and inputs (again, by race, region, and ownership status). We then combined those estimates with estimates of non-farmers' 1900 income from Preston and Haines (1991), which are again adjusted for variation by race and region using 1940's census data (as described in Appendix IVa). ${ }^{25}$

For the OCG cohorts, sons observed in 1962 are assigned income scores based on the 1960 census. Their fathers are assigned the average of 1940- and 1960-based income scores since the retrospective information on their occupation pertains to this period. ${ }^{26}$ Sons observed in the 1973 OCG data are assigned 1970-based scores, whereas their fathers are assigned 1960-based scores. For the NLSY79 cohort, the information on fathers' (or heads') occupations pertains to the 1970s, and so their income scores are 1970-based. We observe the sons' labor market outcomes in 1990 and 2000 and assign income scores based on census data from those years.

One limitation of this score-based approach is that it cannot capture between-cell changes in the wage structure over time in the historical samples. Improvement would be difficult given the fragmentary and non-representative nature of race-specific wage information prior to 1940. Because the analyses focus on ranks within the distribution of scores, between-cell changes in wages would matter only to the extent that the cells change rank. A second limitation is that there is no within-cell variation in score assignments, whereas there is, of course, within-cell variation in true income. For this reason, distributions of scores do not mimic micro-level distributions of earnings. Finally, our measures of economic status only encompass labor income. Differences in wealth accumulation between black and white households with similar income ranks are not reflected in these results but are an important avenue for future research.

We convert assigned income scores into rankings in the national income score distribution in each year. Using the national distribution as a reference point allows us to document economic status relative to the entire population, rather than mobility within subgroups defined by race. ${ }^{27}$ This anchors the discussion in an important historical fact: black Americans were remarkably crowded into the lowest deciles of the national income distribution in the late nineteenth and early twentieth centuries. By focusing on position in the distribution, we would characterize a father-son pair that maintains the same rank as neither upwardly nor downwardly mobile. We find this property

\footnotetext{
${ }^{25}$ The paper's main results using this alternative scoring scheme are in Appendix Table A7.

${ }^{26}$ The 1950 decennial census asks income only of "sample line" individuals, and we quickly encounter sample size problems in the income assignment methodology using 1950 data.

${ }^{27}$ Hertz (2005) and Mazumder (2014) point out that a regression of son's income on father's income for white or black samples separately measures mobility within the group but does not indicate whether groups are converging.
} 
appropriate given the paper's motivation, which is grounded in the relative status of black workers rather than, say, their absolute level of income.

To rank sons and fathers for the historical samples, we first apply the income score assignment methods described above to nationally representative cross-sectional samples for 1880 , 1900, 1910, and 1930 from IPUMS. ${ }^{28}$ Then, we see where men in the linked samples fall relative to the appropriate national distribution in each year. For the OCG and NLSY79 datasets, we rank fathers and sons relative to peers within each dataset.

\section{Summary of Rankings from Cross-Sections}

Figures 1A-1E contain kernel density plots of the distributions of fathers and sons across national income rankings, separately for white and black men in each cohort. The plots highlight the strong concentration of black men at the lower end of the relative income distribution across the full time period, but with diminishing concentrations in the lower tail over time.

Underpinning these cross-sectional distributions are the occupation-based income assignments described above, and we can see how groups line up based on broad occupational categories and race. Table 1, Panel A reports income ranks for all fathers. This provides a check on whether the income assignments result in sensible rankings. Panel B shows how the prevalence of occupational groups varied over time and across races, though we emphasize that the income assignments are based on detailed (not broad) occupational categories. Because farming occupations ("Farmer, owns" and "Farmer, does not own") and white-collar occupations ("White collar, professionals" and "White collar, managerial and clerical") become relatively less and more prevalent over time, respectively, we combine the former into "All Farmers" in the modern samples and the latter into "All White Collar" in the historical samples.

First, we note that the relative rank of the broad categories matches our priors. White-collar and skilled blue-collar workers are relatively highly ranked within race; the "agricultural ladder" appears monotonic in income from farm laborers to non-owner farmers to owner operators; black men earn less than whites within the occupational categories; and the black-white differences in rank

\footnotetext{
${ }^{28}$ The IPUMS national sample includes all fathers of sons aged 0 to 17 in the beginning year (1880 or 1910). We rank all sons against males aged 20 to 37 in the ending year (1900 or 1930). We include only black and white males in these national samples as our race-specific scoring methods run into sample size issues for other races. Practically, this involves eliminating $0.58 \%$ of the national sample in $1880,0.21 \%$ in $1900,0.63 \%$ in 1910 and $0.74 \%$ in 1930.
} 
are larger at higher levels of skill. ${ }^{29}$ Second, the average rank for black fathers in the historical datasets is below the $10^{\text {th }}$ percentile of the national distribution, and black fathers appear to have made little progress in terms of average rank between 1880 and 1910 and no progress between 1910 and circa 1950 (when fathers of 1962 OCG sons would have been of income earning age). Other studies have estimated somewhat larger growth as measured by the black-white ratio of mean income in the pre-1940 period. Margo (2016), for example, estimates a rise in the ratio from 0.28 to 0.32 from 1870 to 1900 and from 0.32 to 0.38 between 1900 and 1940. It is possible for the ratio of mean income to rise without a substantial change in the average black rank, but it is also possible that some growth came from black workers' relative gains within or between occupation-region cells, which are not captured in the historical scoring described above.

For the latter part of the twentieth century, the average rank of black fathers is substantially higher than in the earlier cohorts. For sons in the 1973 OCG, the average rank for black fathers increases to the $15^{\text {th }}$ percentile, as many fewer were reported to have held agricultural occupations relative to the historical samples and to fathers of the 1962 OCG, and as average ranks for black men within non-farm categories increased relative to the previous cohort. Finally, the NLSY79 sample, which measures parent's status in the early 1970s, shows strong evidence of black fathers increasing employment in white collar and higher-skilled blue collar occupations, but also a sizable increase in white fathers' employment in professional and managerial positions (Panel B). The overall result is a rise in the average of black fathers' ranking to approximately the $18^{\text {th }}$ percentile.

\section{Black-White Differences in Intergenerational Mobility Since 1880}

In the analysis that follows, we document intergenerational economic mobility for each cohort of sons in our sample. By "mobility," we mean the movement of sons up or down the percentiles of the national income distribution of similarly aged men relative to the position their fathers held in the distribution of all fathers decades earlier.

First, we show the share of black and white sons who rose in the ranks relative to their father's position - this is "upward rank mobility," as termed by Bhattacharya and Mazumder (2011). When arranged by father's decile, this provides a simple comparison of upward mobility rates for similarly situated children, but it does not capture the magnitude of the differences in the sons' adult

\footnotetext{
${ }^{29}$ Note that black blue collar, semi-skilled workers have higher income ranks than blue collar skilled workers in the 1900 cohort. This inversion is driven by regional concentration; black semi-skilled workers in the 1900 sample are disproportionately located in Maryland and Pennsylvania and, by virtue of region-based assignments, earn a higher income score than skilled black workers in the South.
} 
outcomes. We next use simple descriptive regressions to characterize the expected rank of sons conditional on fathers' rank and race. Finally, to illustrate the consequences of racial differences in mobility, we estimate counterfactual distributions of black sons' income score ranks, in which they experience the net mobility patterns of white sons who were similarly situated in terms of fathers' ranks.

\section{A. Upward Rank Mobility Measures}

Decile-to-decile transition matrices, a common method for displaying rank mobility, provide a rich characterization of mobility patterns, but with two race categories and five cohorts, they are unwieldy for presentation here. ${ }^{30}$ Moreover, as Bhattacharya and Mazumder (2011) and Mazumder (2014) point out, since black fathers tend to rank lower than whites within income deciles, black sons would have to advance further up the ranks to transition over any given decile threshold. Instead, to provide a simple visual summary of racial differences in mobility, we start by illustrating the rate of upward rank mobility (URM), defined as the share of sons whose rank exceeds their father's rank in the national income distribution, conditional on the father's rank being within a certain interval. ${ }^{31}$ Note that a son can exceed his father's rank without transitioning over the decile threshold.

Figures 2A-E summarize upward rank mobility by cohort, including bootstrapped 95\% confidence intervals. ${ }^{32}$ We do not plot results for cells containing fewer than 50 observations. The immediate impression from Figures $2 \mathrm{~A}-\mathrm{E}$ is that conditional on father's decile, there were stark racial differences in upward rank mobility in every cohort we can observe from the late nineteenth century through the end of the twentieth century. ${ }^{33}$ White children had far higher rates of upward rank mobility, implying lower rates of downward mobility because few had exactly the same rank as their parent. Appendix Figure A2 contains downward rank mobility (DRM) estimates, which are the mirror image of the URM estimates shown here.

In the historical samples, for those with the lowest earning fathers (1st decile), between 68 percent (1880-1900) and 85 (1910-1930) percent of white sons exceeded their father's status

\footnotetext{
${ }^{30}$ We provide broad occupational and decile-to-decile transition matrices in Appendix II.

${ }^{31}$ More formally, $U_{\tau, r}=\operatorname{Prob}\left[\left(R_{\text {son }}-R_{\text {father }}\right)>\tau \mid\left(r_{\text {lower }} \leq R_{\text {father }}<r_{\text {upper }}\right)\right]$, where $R_{\text {son } / \text { father }}$ represents rank of son or father; $r_{\text {lower }}$ and $r_{\text {upper }}$ represent the lower and upper bounds of some interval of percentiles (e.g., spanning the first decile of the fathers' distribution); and $\tau$ is equal to or greater than zero. Appendix Table A.5 reports complete URM results for $\tau=0,5$, and 10 .

${ }^{32}$ Bootstrapped standard errors based on 50 draws of 50. As a result, plots are limited to deciles of fathers' income score rank with more than 50 observations. In the modern samples, sample sizes dwindle quickly.

${ }^{33}$ Black men's unconditional rates of upward rank mobility were comparable to those for white men, if not higher. But this reflects that black fathers were concentrated at the bottom of the distribution and that upward mobility rates naturally decline as the father's rank rises, hence the downward slopes in Figures 2A-E.
} 
compared to only 41 percent (1880-1900) or 59 percent (1910-1930) of black sons. The differences at the lowest two deciles in the early samples are both statistically significant and economically important; 97 percent of 1880 black fathers and 94 percent of 1910 black fathers were positioned in the two bottom deciles.

The basic pattern is similar for cohorts of men observed in the 1962 and 1973 OCG surveys. White sons exceeded black sons in upward rank mobility by about 20 to 30 percentage points at the bottom of the fathers' rank distribution. From this perspective, there is no clear evidence that the first cohort of post-Civil Rights era black sons (outcomes measured in 1973) fared substantially better in terms of intergenerational mobility than those that preceded them.

In 1990, racial differences in upward rank mobility appear less pronounced than in the earlier samples, particularly at higher deciles of fathers' income scores. But the differences are still quite large, and they appear to widen with age. That is, results for the NLSY79 sons observed in 2000, rather than 1990, show larger racial differences conditional on fathers' income scores. (See Appendix III.) Mazumder (2014) also finds large racial differences in URM in the NLSY79 data using observed income rather than occupation-based scores.

Consistent with these results, Appendix Table A.5 reports almost universally higher white mobility probabilities within deciles of fathers' income, for every generation observed, and for different thresholds of upward mobility (i.e., the share exceeding father's rank by 0 , 5, or 10 percentiles). In sum, white children have had a far better chance than comparably situated black children of improving upon their father's status throughout U.S. history. The results are not entirely surprising given what is already known about the slow pace of black economic advance and the circumscribed nature of black workers' economic opportunities throughout much of the twentieth century. And yet the disjuncture in outcomes for white and black sons from low-status families is striking because it suggests that that the slow pace of black workers' relative advance was not only, or even primarily, a function of their pre-existing level of poverty. It was also a function of much different likelihoods of getting ahead conditional on starting position throughout post-Civil War history. Figure 2 illustrates this clearly and consistently for the first time with panel data.

\section{B. Expected Outcomes Conditional on Father's Status}

In this section, we use simple descriptive regressions to characterize the racial gap in sons' outcomes conditional on fathers' ranks-the "racial mobility gap." Then, we explore whether additional observable characteristics of fathers, sons, and households can account for the gap. The baseline "full sample" regressions include men (sons) observed in their 20s and 30s; we also report 
estimates that restrict the sample to sons observed at age 30 or higher, allowing more time for their careers to unfold and reducing life-cycle bias in the estimates (Grawe 2006, Haider and Solon 2006).

Panel A of Table 2 presents coefficients on an indicator variable for black sons in each cohort, conditioning only on the fathers' rank. For sons observed in 1900 and 1930, black sons ranked between 22 and 23 percentiles lower than white sons in the "full sample" regressions; the gaps are even larger in the "30+ year old" samples. ${ }^{34}$ In the later cohorts, the racial mobility gaps were 27 percentiles in 1962, 25 in 1973, and 19 in 1990. The NLSY cohort of sons can be reexamined in 2000, and the racial gap is approximately one percentile larger (not shown in Table 2; see Appendix III).

In Panel B of Table 2, we add several control variables reflecting early life circumstances, including measures of fathers' education (when available). In the 1910-30 sample, we observe the literacy rate of fathers, but unfortunately this variable is not available in the full count files for the 1880 census. In the OCG and NLSY samples, we add fixed effects for fathers' educational attainment, measured in years of completed schooling. For all cohorts, we control for whether the family's home was an urban, rural non-farm, or farm residence when the son was co-resident with his parents (i.e., in childhood). Including the combined set of additional characteristics reduces the magnitude of the coefficient on race by no more than 1 point relative to Panel A's results, and otherwise slightly widens differences (1900, 1962, 1973, and 1990 cohorts). Similar results obtain for the subsample of older sons (30-37).

In Panel C, we add controls for the age of sons at the time their occupation is observed, as well as fixed effects for state or region of residence in childhood, while still including the covariates from Panel B. In the historical samples, the childhood location fixed effects are at the state level, whereas for 1962 and 1973 cohorts they are at the region level, and for the 1990 cohort they are at the South/non-South level, reflecting constraints inherent to the datasets. ${ }^{35}$ This specification controls for racial differences in the age structure of the underlying samples as well as differences in place of origin that may affect labor market outcomes. Coefficients on race are somewhat reduced relative to the previous panel, but are still quite large.

Specifications in Panel D add controls for sons' educational attainment or literacy, and the (binary) presence of both parents in the childhood household, which is observable in all samples. In the 1880-1900 sample, we control for sons' literacy, as measured in adulthood in 1900. In the 1910

\footnotetext{
${ }^{34}$ In 1880 subsamples of farm owners and renters, there is a positive correlation between farm value or farm production and sons' rank in 1900 (conditional on fathers' rank), but there is still a large racial mobility gap. ${ }^{35}$ Moving to county over state fixed effects for the earliest cohorts makes for slightly larger racial differences.
} 
to 1930 sample, school attendance (for those over age 5) and literacy (measured in adulthood) are available, and using both reduces the sample size relative to previous panels. From 1962 forward, we see completed grades for all sons. Adding these controls has a relatively minor effect on the size of the racial mobility gap, despite a growing racial difference in the number of single parent households and the rising level of black educational attainment in the modern samples. One caveat is that we only observe school attendance and literacy in the historical samples, two rough proxies for education. In unreported results, we replace the continuous measure of fathers' income rank with fixed effects for income rank deciles to allow for a nonlinear relationship. This change matters little for the results in Table 2.

In addition to the stark racial differences in expected outcomes, Table 2 also shows a consistently positive and statistically significant relationship between father's rank and son's rank. In Panel A's parsimonious regressions, the slope coefficients range from 0.23 to 0.43 , with only small differences in the samples restricted to men age 30 to 37 . Given the nature of income score assignments here, these coefficients are not directly comparable to the intergenerational income elasticities commonly reported in the modern literature, nor are they suitable for strong inferences based on comparisons of coefficients across the different types of datasets we employ. (We discuss concerns about measurement error below.) Most importantly for our purposes, the black-white differences in expected outcomes conditional on fathers' rank were large and persistent. In other words, while there is evidence of mean reversion in the data, it appears that white and black populations were moving toward different means throughout US history. ${ }^{36}$

For additional perspective, Figure 3 illustrates these differences with the raw data, binned by fathers' income percentile and averaged, for easier viewing. The size of the marker is proportional to the number of father-son pairs at each fathers' income percentile. Here, we allow both the intercept and slope estimates to vary by race and sons' cohort, and the slope estimates are generated using the underlying data (equivalent to a regression using the binned data with the marker sizes as weights). Because black fathers are concentrated below the $30^{\text {th }}$ percentile in every dataset, the economic significance of the gap in regression lines in the 0 to 30 range of fathers' rank is clear. We include the NLSY79 cohort of sons observed in both 1990 and 2000 to show that the relatively large slope depicted for black men in 1990 is somewhat sensitive to the age at observation; by 2000, the slope

\footnotetext{
${ }^{36}$ Immigration may contribute to the racial difference if sons of immigrants, almost exclusively white, are highly mobile. Sons of immigrants are a substantial share of the 1900 cohort, but much smaller for subsequent cohorts. See Appendix Table A11 for a comparison of black father-son pairs in each cohort to non-immigrant white father-son pairs. The racial mobility gap is smaller, but only by a few percentiles.
} 
for black sons had fallen and was more similar to that observed for whites. ${ }^{37}$ It is notable that the positive relationship between father's and son's rank is apparent in both populations at all points in time-it was beneficial to be born to a better off black family rather than to an impoverished one, despite the many barriers to advancement.

\section{Robustness of Baseline Estimates}

The racial differences in intergenerational mobility documented above may be sensitive to features of the underlying data or to choices made in the data construction process. To evaluate the robustness of our results, we first address two common sources of bias in the intergenerational mobility literature, lifecycle bias and attenuation bias due to measurement error, before moving on to income assignment assumptions specific to our setting. Each of these concerns is addressed in more detail in Appendix IV.

Lifecycle Bias. A common concern in the empirical intergenerational mobility literature is that father-to-son income correlations tend to vary depending on the ages at which fathers' and sons' incomes are measured. This, in turn, may confound comparisons across samples that observe men at different ages (e.g., see Haider and Solon 2006, Mazumder 2015). We observe sons when they are relatively young compared to what is considered ideal (around age 40) when using modern data and annual income. We acknowledge this limitation but are somewhat less concerned with this issue for two reasons. First, the income scores reflect average income for men in that occupation over all ages (for a given race/region), rather than an individual's actual annual income, which tends to vary substantially with age. Second, we emphasize black-white comparisons of rank within datasets where black and white men are observed with similar age distributions. So, biases that affect black and white men equally would, in a sense, difference out. ${ }^{38}$ Still, it is useful to (a) test the robustness of the paper's main conclusions to samples of sons measured closer to age 40 and (b) utilize the NLSY79 panel structure to capture sons at two points in time, 1990 and 2000. These additional results, detailed more fully in Appendix IV, confirm the paper's main conclusions.

Measurement error. A second common concern is that a single year, or even several years, of fathers' annual income might be a noisy measure of permanent income, tending to attenuate

\footnotetext{
${ }^{37}$ There is some attrition between the 1990 and 2000 observations of the NLSY79 cohort. Restricting to a balanced sample has no effect on the calculated slopes from Figure 3.

${ }^{38}$ If black men progress through occupational hierarchies at slower rates than their white peers over the lifecycle, then we are likely to understate racial differences in sons' status by observing them at relatively young ages. We therefore test the robustness of the paper's main conclusions to samples of sons measured closer to age 40. These results, found in Appendix IV.c., confirm the paper's main conclusions.
} 
measures of intergenerational persistence and to overstate intergenerational mobility. Our approach may have some advantages in this regard. First, rank-rank regressions tend to be less sensitive to measurement error in income than log-linear regressions (Nybom and Stuhler 2017, Ward 2020). Second, occupation-based measures of fathers' status may be more accurate gauges of economic status than single-year measures of annual income. ${ }^{39}$ It is unlikely that many of the relatively poor individuals we observe (e.g., unskilled laborers) were merely having a temporary negative shock to their status or that affluent individuals (e.g., professionals) were having a temporary positive shock. On the other hand, our approach has vulnerabilities. Occupation-based income scores mask permanent individual-level productivity differences within race/occupation/region cells. Moreover, there are bound to be some mismatches between father and son in the historical samples, and some cases where an individual's occupation is misreported.

To assess whether measurement error in economic status is likely to greatly erode the blackwhite mobility gap estimated in regressions such as those in Table 2, we generated simulations in which we added measurement error to both fathers' and sons' income scores and then ran rank-rank regressions. The results from error-ridden data revealed no remarkable difference in the coefficient on race relative to the coefficient from the simulated model without measurement error. ${ }^{40} \mathrm{We}$ concluded that measurement error is unlikely to account for the black-white mobility gap, though the issue is an important one, as pointed out by Ward (2020). ${ }^{41}$

Method of Income Assignment. A concern that is more specific to this study is that the historical samples all rely heavily on the 1940 census data for income assignments, while the 1962, 1973, and 1990 cohort results rely on contemporary census data for income assignments, as

\footnotetext{
${ }^{39}$ For instance, in the historical samples, census enumerators collected occupational information even for those who were temporarily unemployed, thereby avoiding temporary zero income measures. For reference, Björklund and Jäntti (1997, p. 1015) estimate similar intergenerational income elasticities when using 5-year averages of fathers' income and predictions of fathers' income based on occupation and education.

${ }^{40}$ To approximate our empirical setting, the simulation has black fathers and sons earn half of what white fathers and sons earn on average; sons' earnings rise with fathers' earnings by a factor of 0.4 , but with a lower intercept for black sons; black men make up 10 percent of the sample. Classical measurement error is added to both fathers' and sons' earnings because rank-rank regressions are biased by error in both fathers' and sons' earnings (Nybom and Stuhler 2017). The standard deviation of the measurement error is race-specific, corresponding to the ratio of the standard error of income scores to mean income scores for each race based on income scores derived from the1940 U.S. Census. (Assigning the same measurement error to both races does not change our conclusions.) We rank fathers and sons and run rank-rank regressions. The coefficient on race is -21.7 in the results without adding measurement error and -22.3 in the results with measurement error added. ${ }^{41}$ Zach Ward generously ran extra regression specifications at our request, based on Ward (2020). In those specifications, he ran regressions analogous to those in Table 2 for fathers observed in 1910 and sons in 1940. Ward instrumented for fathers' income rank using the same father's income rank in another Census year (1900 or 1920). The racial gap in intergenerational mobility fell from 25 percentiles of the income distribution to 16 percentiles of the income distribution with the instrument, but remained statistically significant.
} 
described above and in the data appendix (Appendix I). We have built two alternative scoring schemes. First, we combine information from the published tables of the 1900 Census of Agriculture for farmers (by race, region, and ownership status) and information from Preston and Haines (1991) for other occupations to form a 1900-based set of scores, which we apply to the 1880-1900 sample. ${ }^{42}$ To introduce flexibility by race and region for the non-farmer assignments, we rely on income ratios derived from the 1940 complete count census files. Second, we undertake analyses using the 1960based scores for all cohorts. Our main conclusions are not much affected by this sensitivity test, as discussed more fully in Appendix IV.a.

\section{Counterfactual Distributions}

Given the racial differences in mobility documented above, it is natural to ask how far such differences go toward explaining differences in the distributions of sons' labor market outcomes. For perspective, we estimate counterfactuals using re-weighting techniques developed in DiNardo, Fortin, and Lemieux (1996). Following their notation, we can specify the joint distribution of sons' status, fathers' status and their respective races as $F\left(s, z, r_{s}, r_{z}\right)$ where $s$ is the status of a son and $z$ is the status of his father; $r_{s}, r_{z}$ are binary variables that indicate the race category for which $s$ or $z$ is observed. The joint distribution of sons' and fathers' status for a given race, $r$, can be written as $F\left(s, z \mid r_{s}=r, r_{z}=r\right)$. In the observed data, $r_{s}=r_{z}$, but as described below, in the counterfactuals $r_{s}$ will not equal $r_{z}$.

In this framework, the marginal density of status for black sons can be written as the integral of the density of sons' status conditional on fathers' status for the black population, $\left(f\left(s \mid z, r_{s}=\right.\right.$ Black $\left.)\right)$, over the distribution of fathers' status for the black population $F\left(z \mid r_{z}=\right.$ Black).

$$
f_{\text {Black }}(s)=\int_{z} f\left(s \mid z, r_{s}=\text { Black }\right) d F\left(z \mid r_{z}=\text { Black }\right) .
$$

The counterfactual seeks to replace the conditional density of black sons' status with the conditional density of white sons' status, while retaining the distribution of black fathers' status. This yields a counterfactual, $f_{c f}(s)$, in which black sons are ranked like whites with similarly ranked fathers.

$$
f_{c f}(s)=\int f\left(s \mid z, r_{s}=\text { White }\right) d F\left(z \mid r_{z}=\text { Black }\right)
$$

\footnotetext{
${ }^{42}$ We thank Laura Salisbury for insight and assistance with the Preston and Haines data. The black-white mobility gap in 1880-1900 is smaller by 3 to 6 percentiles with that scoring scheme (Appendix Table A7).
} 
The key insight of DiNardo, Fortin, and Lemieux (1996) is that a term $\psi_{z}(z)$, which equals $d F\left(z \mid r_{z}=\right.$ Black $) / d F\left(z \mid r_{z}=\right.$ White $)$, can reweight the actual white distribution to produce the counterfactual distribution $f_{c f}(s)$.

$$
f_{c f}(s)=\int f\left(s \mid z, r_{s}=\text { White }\right) \psi_{z}(z) d F\left(z \mid r_{z}=\text { White }\right)
$$

In practice, this entails using estimates from probit regressions to up-weight white observations that are similarly situated to black observations and to down-weight white observations that are not. The result is a counterfactual for black sons that has fathers distributed as they are in the black sample but has the mobility patterns of whites. To be clear, this counterfactual is mechanical in the sense that it simply reshapes a given distribution of ranks. But it does provide quantitative perspective on how strongly the racial mobility gap has played into disparities in outcomes.

Figure 4 shows actual and counterfactual distributions of black sons' rank. These kernel densities are smoothed distributions of the underlying data. ${ }^{43}$ In each panel, the solid lines, representing counterfactual outcomes for black sons, closely follow the long dashed lines representing actual outcomes of white sons. The result of equalizing mobility patterns is stark for all cohorts in the sample. ${ }^{44}$ Equality in transitions, conditional on fathers' income ranks, would have greatly improved the outcomes of black men. The counterfactuals suggest that differences in transition patterns were the primary proximate cause of racial inequality in each generation.

It is not easy to imagine this counterfactual world of rapid black progress-obviously the course of American economic and social history would have been much different if, by 1900, black men had achieved the counterfactual distribution shown in Figure 4A. For reference, in census data, the median black male ranked at the $30^{\text {th }}$ percentile of the national distribution of earned income in $2000 .{ }^{45}$ Thus, it took 100 additional years for the middle of the black male earnings distribution to reach the point that it might have reached in 1900 had black sons in our sample transitioned across income ranks like white sons with similarly ranked fathers.

For a final and simpler counterfactual perspective, we return to the underlying occupational categories. Figure 5 shows the distribution of sons in each of the five cohorts across broad occupation categories (as in Table 1). The solid bars reflect the distribution of black sons in each

\footnotetext{
${ }^{43}$ Densities are estimated using an adaptive bandwidth inversely proportional to the number of observations in a particular area of the distribution. Results for other bandwidth choices are similar.

${ }^{44}$ Summary statistics of dissimilarity between black and white sons' distributions, and counterfactual black distributions under white transitions, are contained in Appendix V. An index of dissimilarity and a Hellinger's distance metric both indicate that imposing white transitions on black sons would reduce the distance between black and white sons' income ranks by between 56 and 80 percent, depending on the metric and cohort year. ${ }^{45}$ Calculated with IPUMS 2000 Census 5\% sample, ranking white and black men, not in school, age 25-59.
} 
cohort, whereas the white bars reflect the distribution of white sons in each cohort. The counterfactual distribution of black sons' occupations in each cohort is shown in gray bars, where once again the counterfactual has black sons transitioning as white sons did from the same occupational category of fathers. ${ }^{46}$ Differences between the actual and counterfactual distribution of black sons in each cohort are stark (comparing solid to gray bars). Again, the proximate cause of black over-representation in lower status occupations, including blue-collar laborers, farm tenants, and, in some cohorts, farm laborers, is the different transition patterns relative to white sons and not the base year's occupational status of fathers. In nearly all cases, the counterfactual distribution of black sons is closer to the actual distribution of white sons than of black.

\section{Conclusion}

After the Civil War, African Americans occupied the lowest rungs on the national income ladder. A substantial literature documents that, more than 150 years later, black men's average and median incomes remain far below those of white men. ${ }^{47}$ Indeed, black men are still disproportionately concentrated in the lowest tiers of the income distribution.

The data and analyses developed in this paper show that in every cohort since 1880, black men have had less upward mobility and lower average income than white men from similarly ranked childhood households. Conditional on father's rank, the size of the black disadvantage has remained large and relatively consistent from the late nineteenth to the end of twentieth century, at around 20 percentile points of the national income score distribution. Our results highlight that racial differences in intergenerational mobility patterns have been an important proximate cause of blackwhite income inequality from the Civil War until today. This finding echoes Otis Duncan's conclusion for mid-century data (1968a) - that the "inheritance of race" is key-but the work here extends Duncan's perspective over a much wider frame of American history. Counterfactuals that equalize mobility across races, conditional on parents' status, result in large relative gains for black men in every generation we examine.

Perhaps the most surprising aspect of the results is the mobility gap's consistency over time, including through the Civil Rights Era, with its major changes in discriminatory policies and

\footnotetext{
${ }^{46}$ Appendix II.b. reports the occupational transition matrices for black and white sons in each cohort.

${ }^{47}$ See, inter alia, Smith and Welch 1989, Donohue and Heckman 1991, Card and Krueger 1992, Carneiro et al. 2005, Fryer 2011, Lang and Manove 2011, Bayer and Charles 2018.
} 
institutions. ${ }^{48}$ We caution that the results do not imply that these major policy and social changes were ineffectual-other economic and social trends since the 1960s may have disproportionately affected black men and may have offset gains that otherwise would have accrued to them from Civil Rights-era policy. In other words, a relatively constant mobility gap may reflect a set of changing and countervailing underlying forces affecting mobility.

Identifying the underlying causes of a racial mobility gap that has persisted since 1880 is beyond the bounds of this paper and clearly merits additional research. Ongoing, contemporaneous labor market discrimination-that is, discrimination in labor markets that directly limits each generation of black men's opportunities for employment and advancement-may contribute to current labor market inequities and is evident in historical settings, as well. ${ }^{49}$ A broader, more dynamic, and historically rooted view would also emphasize the intergenerational implications of past and present discrimination in many forms - in education, housing, and healthcare, in addition to labor markets-that combine and ramify in shaping each generation's opportunities for human capital formation and access to resources that support preparation for and advancement in the labor market. From this perspective, closing the mobility gap may then require a commitment to restructuring the distribution of opportunity for young Americans, beginning long before their arrival on the labor market.

\footnotetext{
${ }^{48}$ Hilger (2016) suggests that institutional changes in the South after 1930 may have increased educational mobility of both black and white children (i.e., weakened the correlation with parents' attainment). In our analyses, this apparently did not translate into sizable changes in the black-white gap in occupational outcomes conditional on parents' outcomes.

${ }^{49}$ For reference, see discussions in Charles and Guryan (2011), Lang and Lehmann (2012), and Neumark (2018). For historical perspective, see, among others, Myrdal (1944), Weaver (1946), Donohue and Heckman (1991), Foote, Whatley, and Wright (2003), and Carruthers and Wanamaker (2017).
} 


\section{References}

Abramitzky, Ran, Leah Platt Boustan, and Katherine Eriksson. 2014. "A Nation of Immigrants: Assimilation and Economic Outcomes in the Age of Mass Migration." Journal of Political Economy 122, 3: 467-506.

Abramitzky, Ran, Leah Platt Boustan, Katherine Eriksson, James J. Feigenbaum, and Santiago Pérez. 2019. “Automated Linking of Historical Data.” NBER Working Paper 25825.

Ancestry.com. Accessed 2020. "U.S. Special Federal Census Non-Population Schedules, 18501880." database and digital images (https://www.ancestrylibrary.com).

Aneja, Abhay P. and Carlos F. Avenancio-Leon. 2019. "The Effect of Political Power on Labor Market Inequality: Evidence from the 1965 Voting Rights Act.” Unpublished working paper.

Bailey, Martha, Connor Cole, Morgan Henderson, and Catherine Massey. 2020. "How Well Do Automated Linking Methods Perform in Historical Samples? Evidence from US Historical Data." Journal of Economic Literature 58, 4: 997-1044.

Bailey, Martha, and Cole, Connor. Autolink.ado. Ann Arbor, MI: Inter-university Consortium for Political and Social Research [distributor], 2019-06-13. https://doi.org/10.3886/E110164V1 Bayer, Patrick and Kerwin Kofi Charles. 2018. "Divergent Paths: A New Perspective on Earnings Differences Between Black and White Men Since 1940." Quarterly Journal of Economics 133, 3: 1459-1501.

Becker, Gary S. and Nigel Tomes. 1979. "An Equilibrium Theory of the Distribution of Income and Intergenerational Mobility." Journal of Political Economy 87, 6: 1153-1189.

Becker, Gary S. and Nigel Tomes. 1986. "Human Capital and the Rise and Fall of Families." Journal of Labor Economics 4, 3: S1-39.

Bhattacharya, Debopam and Bhashkar Mazumder. 2011. "A Nonparametric Analysis of Black-White Differences in Intergenerational Income Mobility in the United States." Quantitative Economics 2, 3: 335-379.

Björklund, Anders and Markus Jäntti. 1997. "Intergenerational Income Mobility in Sweden Compared to the United States." American Economic Review 87, 5: 1009-1018.

Black, Sandra E. and Paul J. Devereux. 2011. "Recent Developments in Intergenerational Mobility." In O. Ashenfelter and D. Card (eds.), Handbook of Labor Economics, Volume 4. Amsterdam: Elsevier, pp. 1487-1541.

Blau, Peter M., Otis Dudley Duncan, David L. Featherman, and Robert M. Hauser. 1999. Occupational Changes in a Generation, 1962-1973: 1962 and 1973 Replicate Data, A User's Guide to the Machine Readable Data File, Volume 1. Ann Arbor, MI: ICPSR 6162.

Borjas, George J. 1994. "Long-Run Convergence of Ethnic Skill Differentials: The Children and Grandchildren of the Great Migration." Industrial and Labor Relations Review 47, 4 (553-573).

Bound, John and Richard B. Freeman. 1992. "What Went Wrong? The Erosion of the Relative Earnings and Employment among Young Black Men in the 1980s," Quarterly Journal of Economics 107: 201- 232 .

Boustan, Leah Platt. 2017. Competition in the Promised Land: Black Migrants in Northern Labor Markets and Cities. Princeton, NJ: Princeton University Press.

Bureau of Labor Statistics, U.S. Department of Labor. 2019. National Longitudinal Survey of Youth 
1979 cohort, 1979-2016 (rounds 1-27). Produced and distributed by the Center for Human Resource Research (CHRR), The Ohio State University. Columbus, OH.

Card, David and Alan B. Krueger. 1992. "School Quality and Black-White Relative Earnings: A Direct Assessment." Quarterly Journal of Economics 107, 1: 151-200.

Carneiro, Pedro. James J. Heckman, and Dimitriy V. Masterov. 2005. "Labor Market Discrimination and Racial Differences in Premarket Factors." Journal of Law and Economics 48, 1: 1-39.

Carruthers, Celeste K. and Marianne H. Wanamaker. 2017. "Separate and Unequal in the Labor Market: Human Capital and the Jim Crow Wage Gap." Journal of Labor Economics 35, 3: 655-696.

Charles, Kerwin Kofi and Jonathan Guryan. 2011. "Studying Discrimination: Fundamental Challenges and Recent Progress." Annual Review of Economics 3, 1: 479-511.

Chetty, Raj, Nathaniel Hendren, Maggie R. Jones, and Sonya R. Porter. 2020. "Race and Economic Opportunity in the United States: An Intergenerational Perspective." Quarterly Journal of Economics 135, 2: 711-783.

Chetty, Raj, Nathaniel Hendren, Patrick Kline, and Emmanuel Saez. 2014. "Where is the Land of Opportunity? The Geography of Intergenerational Mobility in the United States." Quarterly Journal of Economics 129, 4: 1553-1623.

Collins, William J. 1997. "When the Tide Turned: Immigration and the Delay of the Great Migration.” Journal of Economic History 57, 3: 607-632.

Collins, William J. and Robert A. Margo. 2000. "Residential Segregation and Socioeconomic Outcomes: When Did Ghettos Go Bad?” Economics Letters 69, 2: 239-243.

Collins, William J. and Robert A. Margo. 2006. "Historical Perspectives on Racial Differences in Schooling in the United States." In E. Hanushek and F. Welch (eds.) Handbook of Economics of Education. New York: North Holland, pp. 107-154.

Collins, William J. and Robert A. Margo. 2011. "Home Ownership and Race from the End of the Civil War to the Present." American Economic Review, Papers and Proceedings 101, 3: 355-359.

Collins, William J. and Michael Q. Moody. 2017. "Racial Differences in American Women's Labor Market Outcomes: A Long-Run View" In edited S. Averett, L. Argys, and S. Hoffman (eds.) Oxford Handbook on the Economics of Women. New York: Oxford University Press.

Collins, William J. and Marianne H. Wanamaker. 2014. "Selection and Economic Gains in the Great Migration of African Americans: New Evidence from Linked Census Data." American Economic Journal: Applied Economics 6, 1: 220-252.

Collins, William J. and Marianne H. Wanamaker. 2021. "Replication data for: African American Intergenerational Mobility Since 1880." American Economic Association [publisher], Inter-university Consortium for Political and Social Research [distributor]. openicpsr-128442.

Cutler, David M., Edward L. Glaeser and Jacob L. Vigdor. 1999. "The Rise and Decline of the American Ghetto." Journal of Political Economy 107, 3: 455-506.

Dahl, Molly and Thomas DeLeire. 2008. “The Association between Children's Earnings and Fathers' Lifetime Earnings: Estimates Using Administrative Data.” Institute for Research on Poverty Discussion Paper 1342-08.

Darity, William, Jr., Jason Dietrich, and David K. Guilkey. 2001. "Persistent Advantage or Disadvantage? Evidence in Support of the Intergenerational Drag Hypothesis." American Journal of 
Economics and Sociology 60, 2: 435-470.

Davis, Jonathan and Bhashkar Mazumder. 2018. "Racial and Ethnic Differences in the Geography of Intergenerational Mobility.” Working paper: https://dx.doi.org/10.2139/ssrn.3138979.

Derenoncourt, Elora. 2019. "Can You Move to Opportunity? Evidence from the Great Migration." Unpublished working paper.

Derenoncourt, Elora and Claire Montialoux. 2020. "Minimum Wages and Racial Inequality." Quarterly Journal of Economics, forthcoming: https://doi.org/10.1093/qje/qjaa031.

DiNardo, John, Nicole M. Fortin, and Thomas Lemieux. 1996. "Labor Market Institutions and the Distribution of Wages, 1973-1992: A Semiparametric Approach." Econometrica. 64, 5: 1001-1044.

Donohue, John J. III, and James Heckman. 1991. "Continuous versus Episodic Chance: The Impact of Civil Rights Policy on the Economic Status of Blacks." Journal of Economic Literature 29, 4: 1603-1643.

Duncan, Otis Dudley. 1968a. "Inheritance of Poverty or Inheritance of Race?” In D. P. Moynihan (ed.), On Understanding Poverty. New York: Basic Books, pp. 85-110.

Duncan, Otis Dudley. 1968b. "Patterns of Occupational Mobility Among Negro Men." Demography 5, 1: 11-22.

Engerman, Stanley L. 1966. "The Economic Impact of the Civil War.” Explorations in Entrepreneurial History, second series, 3, 3: 176-199.

Featherman, David L. and Robert M. Hauser. 1976. "Changes in the Socioeconomic Stratification of the Races, 1962-73.” American Journal of Sociology 82, 3: 621-51.

Feigenbaum, James. 2018. "Multiple Measures of Historical Intergenerational Mobility: Iowa 1915 to 1940." Economic Journal 128, 612: F446-F481.

Ferrie, Joseph P. 1996. "A New Sample of Males Linked from the Public Use Microdata Sample of the 1850 US Federal Census of Population to the 1860 US Federal Census Manuscript Schedules." Historical Methods 29, 4: 141-156.

Foote, Christopher L., Warren C. Whatley, and Gavin Wright. 2003. "Arbitraging a Discriminatory Labor Market: Black Workers at the Ford Motor Company, 1918-1947." Journal of Labor Economics 21, 3: 493-532.

Freeman, Richard. 1981. "Black Economic Progress after 1964: Who Has Gained and Why?" In S. Rosen (ed.), Studies in Labor Markets. Chicago, IL: University of Chicago Press, pp. 247-294.

Fryer, Roland. 2011. "Racial Inequality in the $21^{\text {st }}$ Century: The Declining Significance of Race." In Handbook of Labor Economics, Volume 4B. Amsterdam: Elsevier, pp. 855-971.

Goldenweiser, E.A. and Leon E. Truesdell. 1924. Farm Tenancy in the United States. Washington, DC: Government Printing Office.

Goldin, Claudia. 1990. Understanding the Gender Gap: An Economic History of American Women. New York: Oxford University Press.

Goldin, Claudia and Robert A. Margo. 1992. "The Great Compression: The US Wage Structure at Mid-Century." Quarterly Journal of Economics 107, 1-34.

Grawe, Nathan. 2006 "Lifecycle Bias in Estimates of Intergenerational Earnings Persistence." Labour Economics 13, 5:551-570. 
Grossman, James R. Land of Hope: Chicago, Black Southerners, and the Great Migration. Chicago: University of Chicago Press, 1989.

Haider, Steven and Gary Solon. 2006. "Life-Cycle Variation in the Association between Current and Lifetime Earnings.” American Economic Review 96, 4: 1308-1320.

Haines, Michael R., and Inter-university Consortium for Political and Social Research. 2010. Historical, Demographic, Economic, and Social Data: The United States, 1790-2002. Inter-university Consortium for Political and Social Research [distributor]. https://doi.org/10.3886/ICPSR02896.v3

Hertz, Tom. 2005. "Rags, Riches, and Race: The Intergenerational Economic Mobility of Black and White Families in the United States." In S. Bowles, H. Gintis, and M. Osborne (eds.), Unequal Chances: Family Background and Economic Success. New York: Russell Sage and Princeton University Press, pp. 165-191.

Higgs, Robert. 1977. Competition and Coercion: Blacks in the American Economy, 1865-1914. New York, NY: Cambridge University Press.

Higgs, Robert. 1982. "Accumulation of Property by Southern Blacks before World War I." American Economic Review 72, 4: 725-737.

Hilger, Nathaniel G. 2016. "The Great Escape: Intergenerational Mobility in the United States since 1940.” NBER Working Paper 21217.

Hout, Michael. 1984. "Occupational Mobility of Black Men: 1962 to 1973." American Sociological Review 49, 3: 308-322.

Hutchinson, William K. and Robert A. Margo. 2006. "The Impact of the Civil War on Capital Intensity and Labor Productivity in Southern Manufacturing." Explorations in Economic History 43, 4: 689-704.

Inwood, Kris, Chris Minns, and Fraser Summerfield. 2019. "Occupational Earnings Scores and Immigrant Assimilation: Evidence from the Canadian Census." Explorations in Economic History 72 (April): 114-122.

Isaacs, Julia B. 2008. "Economic Mobility of Black and White Families." In by J.B. Isaacs, I.V. Sawhill, and R. Haskins (eds.) Getting Ahead or Losing Ground: Economic Mobility in America. Washington, DC: Brookings Institution, pp: 71-79.

Kain, John F. 1968. "Housing Segregation, Negro Employment, and Metropolitan Decentralization." The Quarterly Journal of Economics 82, 2: 175-197.

Klarman, Michael J. 2004. From Jim Crow to Civil Rights: The Supreme Court and the Struggle for Racial Equality. New York, NY: Oxford University Press.

Kousser, J. Morgan. 1974. The Shaping of Southern Politics: Suffrage Restrictions and the Establishment of the One-Party South. New Haven: CT: Yale University Press.

Lang, Kevin, and Jee-Yeon K. Lehmann. 2012. "Racial Discrimination in the Labor Market: Theory and Empirics." Journal of Economic Literature 50, 4: 959-1006

Lang, Kevin, and Michael Manove. 2011. "Education and Labor Market Discrimination.” American Economic Review 101, 4: 1467-96.

Logan, Trevon and John Parman. 2017. "The National Rise in Residential Segregation." Journal of Economic History 77, 1: 127-70.

Long, Jason and Joseph Ferrie. 2013. "Intergenerational Occupational Mobility in Britain and the 
U.S. Since 1850.” American Economic Review 103, 4: 1109-1137.

Loury, Glenn C. 1977. “A Dynamic Theory of Racial Income Differences.” In P. A. Wallace and A. LaMond (eds.) Women, Minorities, and Employment Discrimination. Lexington, MA: Lexington Books.

Lundberg, Shelly and Richard Startz. 1998. "On the Persistence of Racial Inequality." Journal of Labor Economics 16, 2: 292-323.

Maloney, Thomas N. 1994. "Wage Compression and Wage Inequality between Black and White Males in the United States, 1940-1960." Journal of Economic History 54, 2: 358-81.

Manduca, Robert. 2018. "Income inequality and the Persistence of Racial Economic Disparities." Sociological Science 5: 182-205.

Margo, Robert A. 1984. "Accumulation of Property by Southern Blacks before World War I:

Comment and Further Evidence." American Economic Review 74, 4: 768-776.

Margo, Robert A. 1990. Race and Schooling in the South, 1880-1950: An Economic History. Chicago, IL: University of Chicago Press.

Margo, Robert A. 1995. "Explaining Black-White Wage Convergence, 1940-1950." ILR Review 48(3): 470-481.

Margo, Robert A. 2004. "The North-South Wage Gap, Before and After the Civil War.” In D. Eltis, F. Lewis, and K. Sokoloff (eds.) Slavery in the Development of the Americas. New York: Cambridge University Press, pp. 324-351.

Margo, Robert A. 2016. "Obama, Katrina, and the Persistence of Racial Inequality." Journal of Economic History 76(2): 301-341.

Massey, Douglas S. and Nancy Denton. 1993. American Apartheid: Segregation and the Making of the Underclass. Cambridge, MA: Harvard University Press.

Mazumder, Bhashkar. 2005. "Fortunate Sons: New Estimates of Intergenerational Mobility in the U.S. Using Social Security Earnings Data.” Review of Economics and Statistics 87(2): 235-255.

Mazumder, Bhashkar. 2014. "Black-White Differences in Intergenerational Economic Mobility in the US." Economic Perspectives 38, 1: 1-18.

Mazumder, Bhashkar. 2015. "Estimating Intergenerational Elasticity and Rank Association in the United States: Overcoming the Current Limitations of Tax Data." Federal Reserve Bank of Chicago Working Paper 2015-04.

Minnesota Population Center. 2017. North Atlantic Population Project: Complete Count Microdata. Version 2.3 [dataset]. Minneapolis: Minnesota Population Center.

http://doi.org/10.18128/D040.V2.3.

Myrdal, Gunnar. 1944. An American Dilemma: The Negro Problem and Modern Democracy. New York, NY: Harper \& Row.

Naidu, Suresh. 2010. "Recruitment Restrictions and Labor Markets: Evidence from the Postbellum U.S. South.” Journal of Labor Economics 28, 2: 413-45.

Neal, Derek. 2004. “The Measured Black-White Wage Gap among Women Is Too Small.” Journal of Political Economy 112, 1, pt 2: S1-S28.

Nybom, Martin and Jan Stuhler. 2017. "Biases in Standard Measures of Intergenerational Income 
Dependence." Journal of Human Resources 52, 3: 800-825.

Olivetti, Claudia and M. Daniele Paserman. 2015. "In the Name of the Son (and the Daughter): Intergenerational Mobility in the United States." American Economic Review 105, 8: 2695-2724.

Oubre, Claude F. 1978. Forty Acres and a Mule: The Freedmen's Bureau and Black Land Ownership. Baton Rouge, LA: LSU Press.

Pattillo-McCoy, Mary. 1999. Black Picket Fences: Privilege and Peril among the Black Middle Class. Chicago, IL: University of Chicago Press.

Preston, Samuel H. and Michael R. Haines. 1991. Fatal Years: Child Mortality in Late NineteenthCentury America. Princeton, NJ: Princeton University Press.

Ransom, Roger L. and Richard Sutch. 2001 [1977]. One Kind of Freedom: The Economic Consequences of Emancipation. Cambridge, UK: Cambridge University Press.

Ransom, Roger L. 2006. "Table Eh1-7: Population of the Slave States, by State, Race, and Slave Status: 1860-1870." In S. Carter et al. (eds.), Historical Statistics of the United States, Millennial Edition. New York: Cambridge University Press, p. 5-783.

Ruggles, Steven, Katie Genadek, Ronald Goeken, Josiah Grover, and Matthew Sobek. 2015. Integrated Public Use Microdata Series: Version 6.0 [database]. Minneapolis: University of Minnesota. http://doi.org/10.18128/D010.V6.0. Provided via National Bureau of Economic Research.

Saavedra, Martin and Tate Twinam. 2020. "A Machine Learning Approach to Improving Occupational Income Scores.” Explorations in Economic History 75.

Sacerdote, Bruce. 2005. "Slavery and the Intergenerational Transmission of Human Capital." Review of Economics and Statistics 87, 2: 217-234.

Sharkey, Patrick. 2013. Stuck in Place: Urban Neighborhoods and the End of Progress toward Racial Equality. Chicago, IL: University of Chicago Press.

Smith, James P. 1984. "Race and Human Capital.” American Economic Review 74, 4: 685-698.

Smith, James P. and Finis Welch. 1989. "Black Economic Progress After Myrdal.” Journal of Economic Literature 27, 2: 519-64.

Solon, Gary. 1992. "Intergenerational Income Mobility in the United States." American Economic Review 82 (June): 393-408.

Solon, Gary. 1999. "Intergenerational Mobility in the Labor Market.” In O. Ashenfelter and D. Card (eds.), Handbook of Labor Economics, Volume 3A. Amsterdam: Elsevier, pp. 1762-1796.

Tan, Hui Ren. 2019. “A Different Land of Opportunity: The Geography of Intergenerational Mobility in the Early $20^{\text {th }}$-Century US." Working paper.

U.S. Department of Agriculture. 1957. Major Statistical Series of the U.S. Department of Agriculture. Volumes 3 and 7. Washington, DC: Government Printing Office.

Ward, Zachary. 2020. "Intergenerational Mobility in American History: Accounting for Race and Measurement Error.” Unpublished working paper.

Weaver, Robert C. 1946. Negro Labor: A National Problem. New York, NY: Harcourt, Brace, and Co.

Williams, Heather A. 2005. Self-Taught: African American Education in Slavery and Freedom. Chapel Hill, NC: University of North Carolina Press. 
Wilson, William Julius. 1987. The Truly Disadvantaged: The Inner City, the Underclass, and Public Policy. Chicago, IL: University of Chicago Press.

Woodman, Harold D. 1995. New South—New Law. Baton Rouge, LA: Louisiana State University Press.

Woodson, Carter G. A Century of Negro Migration. Washington, DC: Association of Negro Life and History, 1918 [Reprinted in 2002, Mineola, NY: Dover Publications.]

Wright, Gavin. 1986. Old South, New South: Revolutions in the Southern Economy since the Civil War. New York: Basic Books.

Wright, Gavin. 2013. Sharing the Prize: The Economics of the Civil Rights Revolution in the American South. Cambridge, MA: Harvard University Press. 
TABLE 1: NATIONAL INCOME SCORE RANKINGS AND SHARES BY OCCUPATION, BLACK AND WHITE FATHERS

PANEL A: FATHERS' AVERAGE INCOME SCORE RANKS BY OCCUPATION CATEGORY

Sons' Cohort Year

Farmer, owns

Farmer, does not own

Farm laborer

White collar, professionals

White collar, managerial and clerical

Blue collar, skilled

Blue collar, semi skilled

Blue collar, laborer

AVERAGE

N

White Black

56.6

56.6
42.4

13.0

91.4*

65.5

52.9

21.7

57.1

282,980

8.4
3.9
2.3

1930

Black

1962

White Black

1973

White Black

White Black

$53.9 \quad 8.0$

$42.0 \quad 3.9$

$14.6 \quad 2.5$

$43.5^{*} \quad 3.3$

$45.5 \quad 4.7$

60.3

4.0

$\begin{array}{ll}8.4 & 1.7\end{array}$

10.6

2.1

$87.7 \quad 38.1$

86.8

18.6

80.8

1.4

$64.0 \quad 23.0$

60.4

50.3

$\begin{array}{llllll}61.1 & 20.7 & 59.8 & 23.9 & 54.2 & 23.0\end{array}$

42.0

$\begin{array}{llllll}61.1 & 20.7 & 59.8 & 23.9 & 54.2 & 23.0\end{array}$

20.7

$66.5 \quad 20.3$

39.3

14.0

$41.3 \quad 16.0$

$32.6 \quad 14.5$

$23.8 \quad 12.6$

16.3

8.29

$19.4 \quad 10.0$

17.7

$53.7 \quad 10.2$

55.6

13,849

15.3
1,175

56.4

$\begin{array}{rrr}7.1 & 56.4 & 8.0 \\ 25,119 & 1,415,312 & 82,223\end{array}$

PANEL B: FATHERS' SHARE BY OCCUPATION CATEGORY (\%)

\section{Sons' Cohort Year}

Farmer, owns

Farmer, does not own

Farm laborer

White collar, professionals

White collar, managerial and clerical

Blue collar, skilled

Blue collar, semi skilled

1900

\begin{tabular}{rr}
\multicolumn{2}{c}{1900} \\
White & Black \\
43.6 & 12.5 \\
11.0 & 37.5 \\
2.6 & 20.5 \\
13.9 & 1.1 \\
12.5 & 2.5 \\
9.5 & 3.9 \\
7.0 & 22.1
\end{tabular}

Blue collar, laborer

Notes and Sources: Table presents average income score rankings (Panel A) and percentage distribution (Panel B) of sample fathers by broad occupation category for each cohort of sons in our data. See text for definition of "father" in each sample. Average income score ranks for fathers are not monotonic in skill within the blue-collar category due to geographic concentrations. Specifically, in 1880, black fathers in the semi-skilled blue collar category were disproportionately located ouside the South, where incomes were higher. Sample sizes for regressions in Table 2 are somewhat smaller for 1962, 1973, and 1990 samples because of missing variables.

*Farming occupations (Farmer, owns and Farmer, does not own) are collapsed in the modern samples; White collar occupations are collapsed in historical samples. 
TABLE 2: SONS' INCOME RANK REGRESSIONS, INCLUDING FATHERS' INCOME SCORE RANK AND RACE

\begin{tabular}{|c|c|c|c|c|c|c|c|c|c|c|}
\hline \multirow[b]{2}{*}{ Sons' Cohort Year } & \multicolumn{5}{|c|}{ Full Sample } & \multicolumn{5}{|c|}{ Age 30-37 only } \\
\hline & 1900 & 1930 & 1962 & 1973 & 1990 & 1900 & 1930 & 1962 & 1973 & 1990 \\
\hline \multicolumn{11}{|c|}{ PANEL A: WITH FATHERS' INCOME RANK CONTROLS } \\
\hline BLACK & $\begin{array}{c}-22.50 * * * \\
(0.429)\end{array}$ & $\begin{array}{c}-22.82 * * * \\
(0.0711)\end{array}$ & $\begin{array}{c}-27.46^{* * * *} \\
(0.799)\end{array}$ & $\begin{array}{c}-25.19 * * * \\
(0.700)\end{array}$ & $\begin{array}{c}-18.84^{* * * *} \\
(1.546)\end{array}$ & $\begin{array}{c}-29.19 * * * \\
(0.750)\end{array}$ & $\begin{array}{c}-27.04 * * * \\
(0.119)\end{array}$ & $\begin{array}{c}-27.02 * * * \\
(1.381)\end{array}$ & $\begin{array}{c}-26.94 * * * \\
(1.335)\end{array}$ & $\begin{array}{c}-20.23 * * * \\
(2.547)\end{array}$ \\
\hline Parent's Income Rank & $\begin{array}{l}0.432 * * * \\
(0.00663)\end{array}$ & $\begin{array}{c}0.398 * * * \\
(0.000890)\end{array}$ & $\begin{array}{c}0.308 * * * \\
(0.0109)\end{array}$ & $\begin{array}{l}0.227 * * * \\
(0.00882)\end{array}$ & $\begin{array}{c}0.258 * * * \\
(0.0238)\end{array}$ & $\begin{array}{c}0.399 * * * \\
(0.0113)\end{array}$ & $\begin{array}{l}0.383^{* * *} \\
(0.00136)\end{array}$ & $\begin{array}{c}0.336 * * * \\
(0.0178)\end{array}$ & $\begin{array}{c}0.267 * * * \\
(0.0152)\end{array}$ & $\begin{array}{c}0.272 * * * \\
(0.0391)\end{array}$ \\
\hline $\mathrm{N}$ & 308,099 & $1,497,535$ & 9,025 & 13,848 & 2,620 & 100,912 & 604,441 & 3,361 & 4,267 & 1,002 \\
\hline R-Squared & 0.354 & 0.307 & 0.226 & 0.164 & 0.149 & 0.416 & 0.341 & 0.256 & 0.200 & 0.163 \\
\hline
\end{tabular}

PANEL B: ADD FATHERS' EDUCATION OR LITERACY, FARM, AND URBAN CONTROLS

\begin{tabular}{|c|c|c|c|c|c|c|c|c|c|c|}
\hline BLACK & $\begin{array}{c}-25.17 * * * \\
(0.392)\end{array}$ & $\begin{array}{c}-22.42 * * * \\
(0.0714)\end{array}$ & $\begin{array}{c}-28.18 * * * \\
(0.781)\end{array}$ & $\begin{array}{c}-25.62 * * * \\
(0.697)\end{array}$ & $\begin{array}{c}-19.67 * * * \\
(1.563)\end{array}$ & $\begin{array}{c}-31.22 * * * \\
(0.702)\end{array}$ & $\begin{array}{c}-25.93 * * * \\
(0.121)\end{array}$ & $\begin{array}{c}-27.84 * * * \\
(1.357)\end{array}$ & $\begin{array}{c}-27.16^{* * * *} \\
(1.359)\end{array}$ & $\begin{array}{c}-20.79 * * * \\
(2.597)\end{array}$ \\
\hline Parent's Income Rank & $\begin{array}{l}0.361 * * * \\
(0.00678)\end{array}$ & $\begin{array}{c}0.285^{* * *} * \\
(0.000903)\end{array}$ & $\begin{array}{c}0.224 * * * \\
(0.0120)\end{array}$ & $\begin{array}{l}0.162 * * * \\
(0.00989)\end{array}$ & $\begin{array}{c}0.187 * * * \\
(0.0269)\end{array}$ & $\begin{array}{c}0.345 * * * \\
(0.0114)\end{array}$ & $\begin{array}{l}0.276^{* * * *} \\
(0.00137)\end{array}$ & $\begin{array}{c}0.237 * * * \\
(0.0198)\end{array}$ & $\begin{array}{c}0.176 * * * \\
(0.0171)\end{array}$ & $\begin{array}{c}0.227 * * * \\
(0.0456)\end{array}$ \\
\hline R-Squared & 0.409 & 0.381 & 0.259 & 0.182 & 0.19 & 0.451 & 0.409 & 0.299 & 0.235 & 0.216 \\
\hline
\end{tabular}

PANEL C: ADD AGE AND STATE/REGION OF ORIGIN FIXED EFFECTS

\begin{tabular}{lcccccccccc}
\hline BLACK & $-23.49 * * *$ & $-21.70 * * *$ & $-26.83 * * *$ & $-22.98 * * *$ & $-18.94 * * *$ & $-28.89 * * *$ & $-24.84 * * *$ & $-28.20 * * *$ & $-25.30 * * *$ & $-19.54 * * *$ \\
& $(0.453)$ & $(0.0751)$ & $(0.776)$ & $(0.677)$ & $(1.569)$ & $(0.836)$ & $(0.128)$ & $(1.278)$ & $(1.323)$ & $(2.634)$ \\
Parent's Income Rank & $0.269 * * *$ & $0.214 * * *$ & $0.168 * * *$ & $0.125 * * *$ & $0.168 * * *$ & $0.267 * * *$ & $0.219 * * *$ & $0.200 * * *$ & $0.129 * * *$ & $0.204 * * *$ \\
& $(0.00393)$ & $(0.000939)$ & $(0.0120)$ & $(0.00981)$ & $(0.0273)$ & $(0.00646)$ & $(0.00146)$ & $(0.0202)$ & $(0.0178)$ & $(0.0461)$ \\
R-Squared & 0.462 & 0.430 & 0.329 & 0.277 & 0.204 & 0.471 & 0.425 & 0.320 & 0.256 & 0.229 \\
\hline
\end{tabular}

PANEL D: ADD SONS' EDUCATION OR LITERACY CONTROLS + PARENTAL PRESENCE

\begin{tabular}{lcccccccccc}
\hline BLACK & $-21.82 * * *$ & $-20.90 * * *$ & $-26.75 * * *$ & $-23.37 * * *$ & $-20.61 * * *$ & $-27.00 * * *$ & $-23.89 * * *$ & $-28.08 * * *$ & $-24.98 * * *$ & $-21.00 * * *$ \\
& $(0.435)$ & $(0.0753)$ & $(0.778)$ & $(0.619)$ & $(1.489)$ & $(0.812)$ & $(0.128)$ & $(1.297)$ & $(1.224)$ & $(2.520)$ \\
Parent's Income Rank & $0.266 * * *$ & $0.210 * * *$ & $0.173 * * *$ & $0.0787 * * *$ & $0.113 * * *$ & $0.264 * * *$ & $0.211 * * *$ & $0.206 * * *$ & $0.0785 * * *$ & $0.155 * * *$ \\
& $(0.00393)$ & $(0.000938)$ & $(0.0126)$ & $(0.00990)$ & $(0.0286)$ & $(0.00647)$ & $(0.00146)$ & $(0.0214)$ & $(0.0176)$ & $(0.0492)$ \\
R-Squared & 0.465 & 0.433 & 0.329 & 0.368 & 0.308 & 0.475 & 0.430 & 0.320 & 0.378 & 0.333 \\
\hline
\end{tabular}

Notes and Sources: Table contains estimated coefficients from an OLS regression where Sons' Income Rank is regressed on an indicator for Black as well as Fathers' income rank (Panel A), parental education or literacy (not available in 1900), farm residence, and urban residence (Panel B), age and (childhood) state of origin fixed effects (Panel C), and sons' school attendance (1930 sample), sons' education level (1962, 1973, 1990 samples), sons' literacy in adulthood (1900, 1930 samples) and an indicator for the presence of both parents in the childhood home (Panel D). Standard errors in parentheses. Age range in the Full Sample varies by cohort: 20-37 for 1900 and 1930 cohorts; 20-43 for 1962 and 1973 cohorts; 25 -33 for 1990 cohort. The set of columns on the right restricts all samples to a common support of sons' ages at observation: $30-37$. Sample sizes do not change as you move down a column with the exception of Panel D for the 1930 cohort where sample size for Panel D column 2 is 604,441. School attendance is not measured for ages younger than 6 in the year of childhood observation (1910) so adding sons' education controls in the last panel effectively limits the sample to those aged 26 and older in 1930 . See text for definition of "father" in each sample. 
FIGURE 1: KERNEL DENSITY PLOTS: INCOME SCORE PERCENTILES,

BLACK AND WHITE FATHERS AND SONS BY COHORT

PANEL A: 1900 COHORT

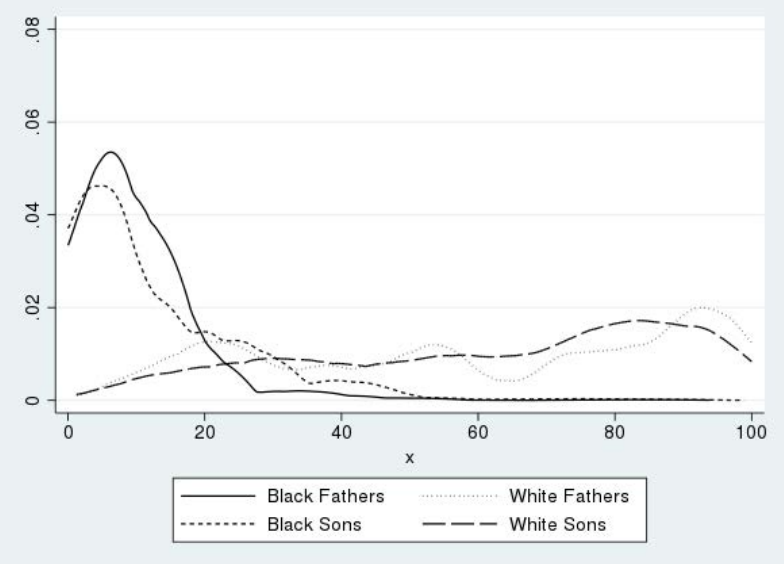

PANEL B: 1930 COHORT

PANEL C: 1962 COHORT
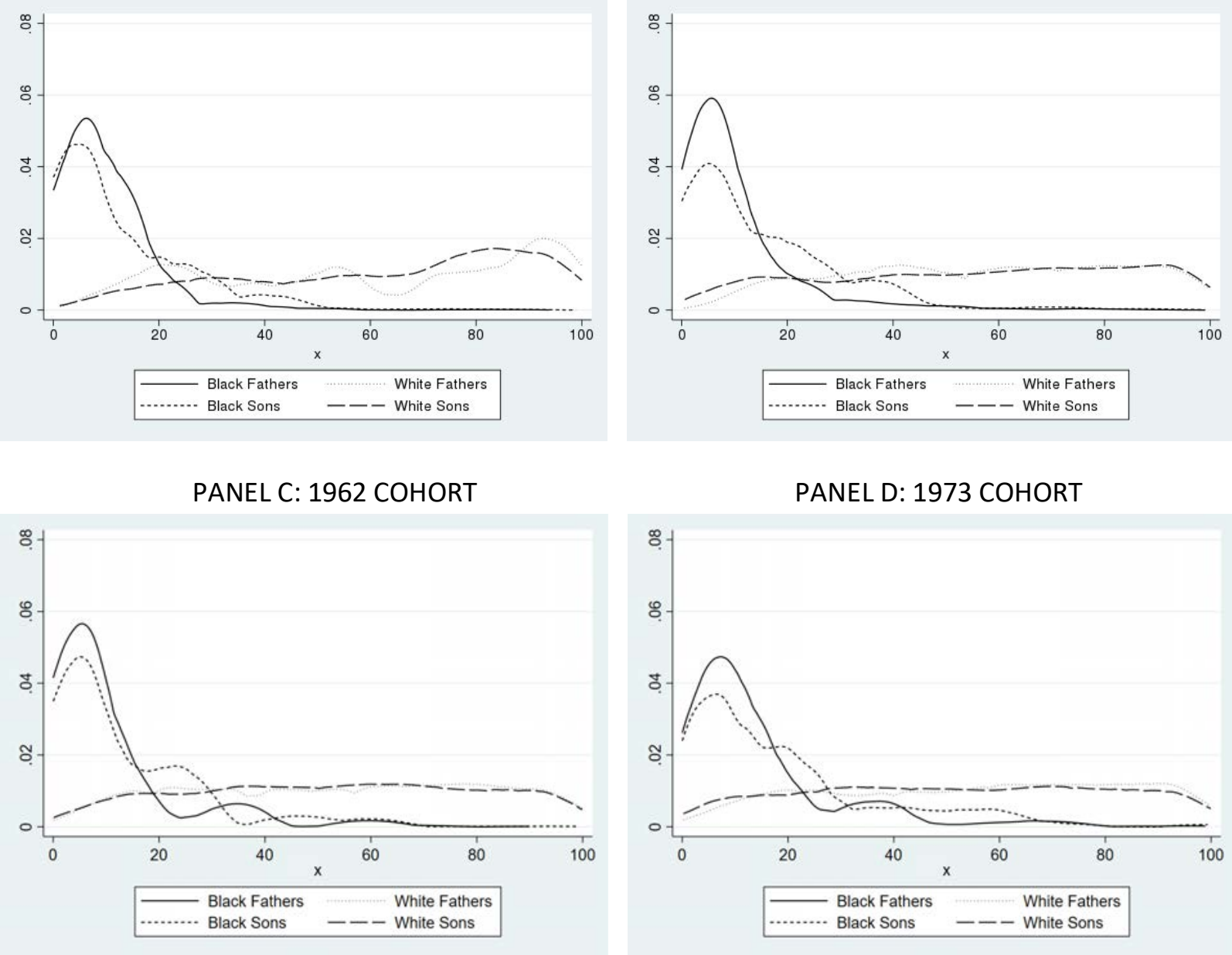

PANEL D: 1973 COHORT

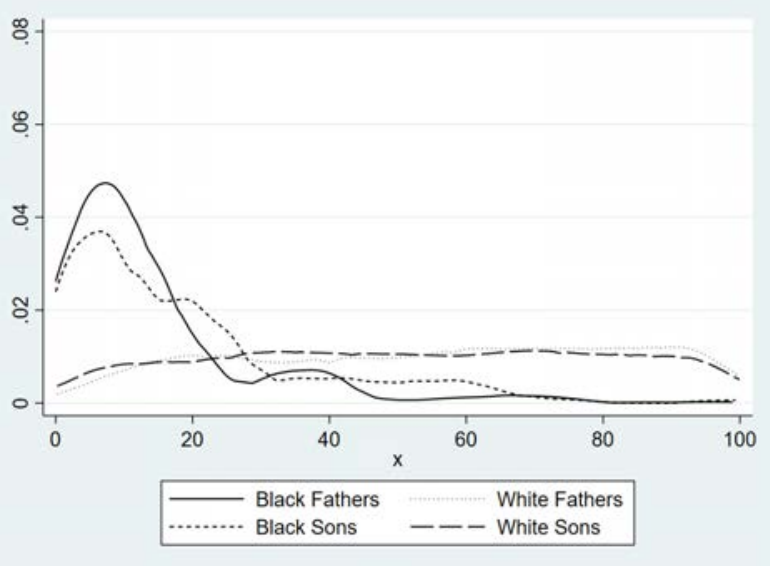

PANEL E: 1990 COHORT

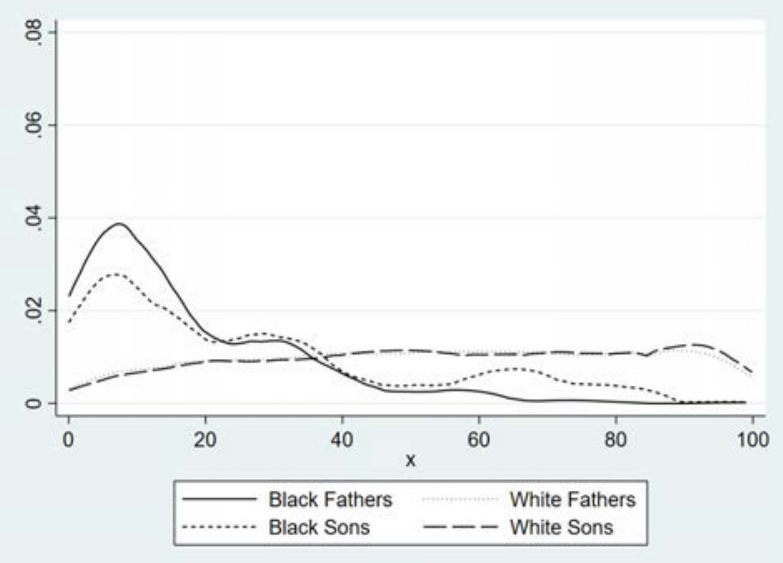

Notes and Sources: See main paper for sources and sample construction. 


\section{FIGURE 2: UPWARD RANK MOBILITY BY FATHERS' INCOME SCORE DECILE, BY COHORT AND RACE}

PANEL A: 1900 COHORT

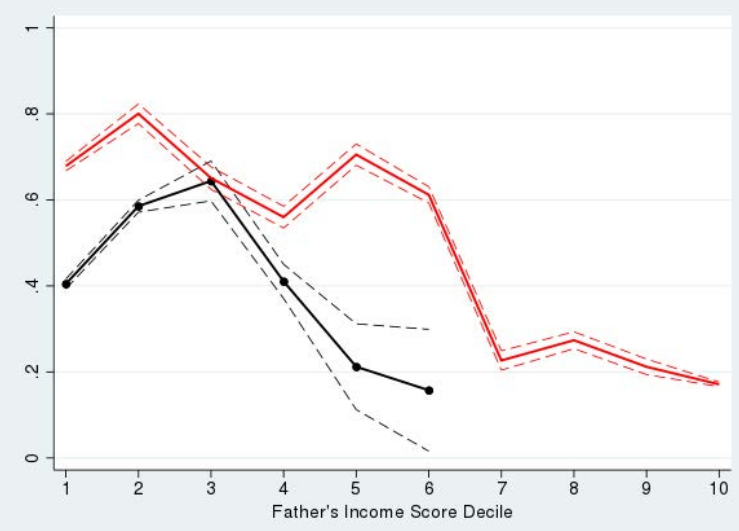

PANEL C: 1962 COHORT

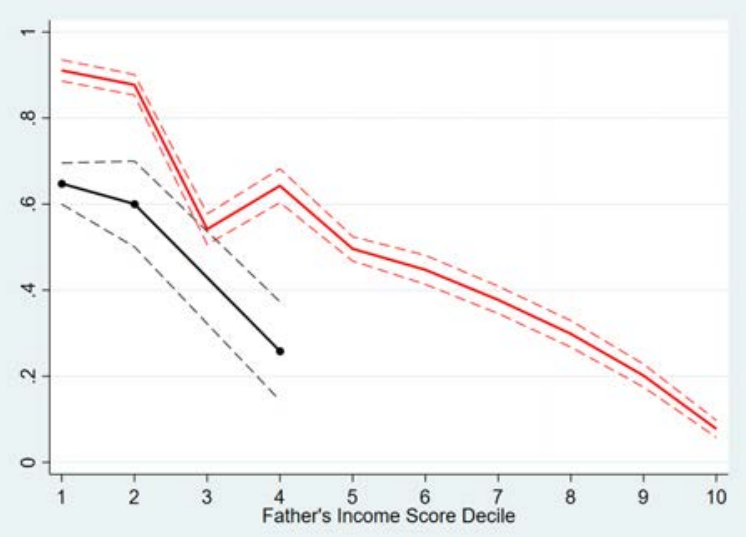

PANEL B: 1930 COHORT

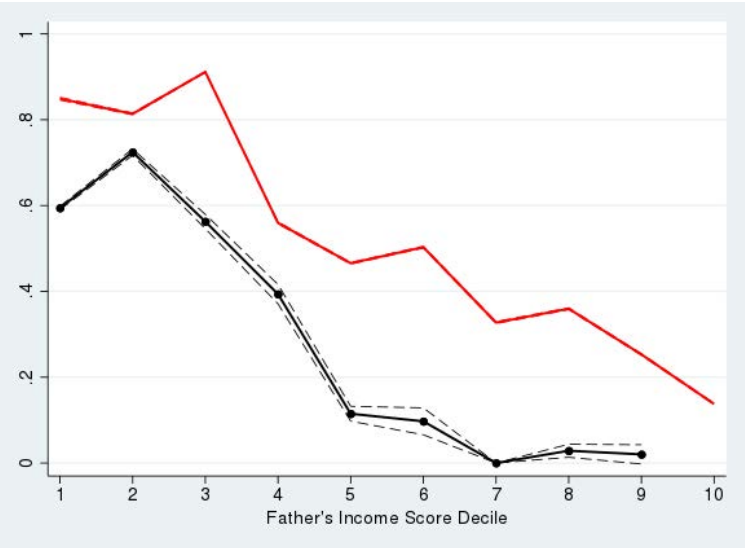

PANEL D: 1973 COHORT

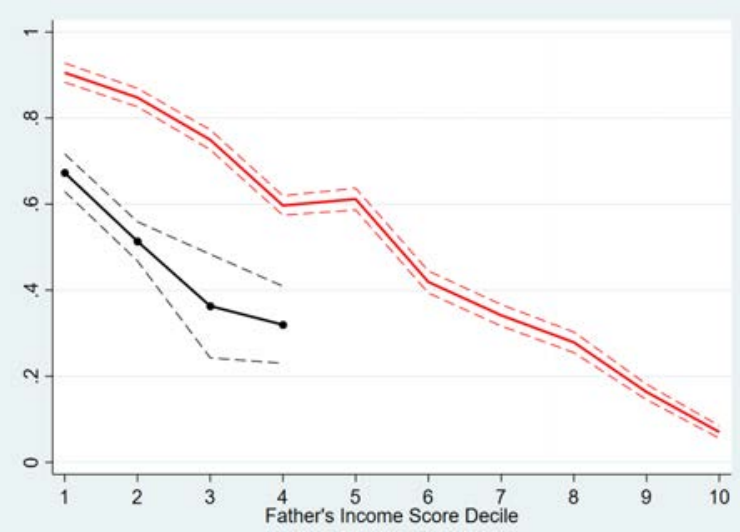

PANEL E: 1990 COHORT

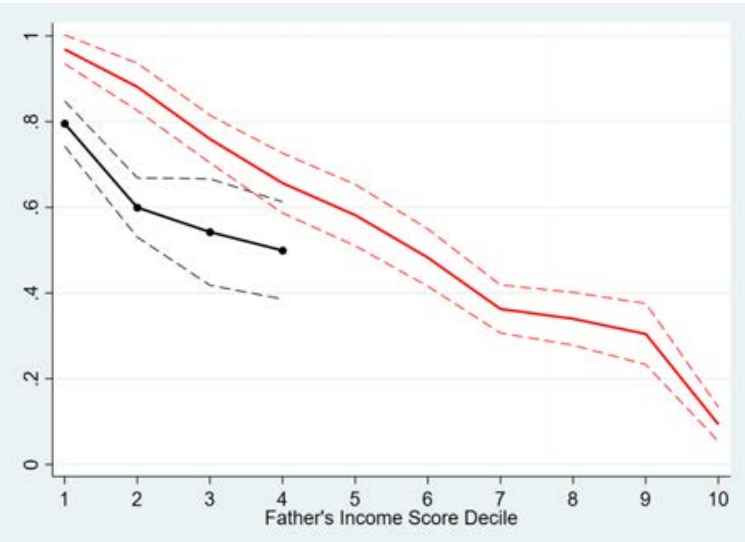

Notes: Black solid lines represent black sons' Upward Rank Mobility values at each value of head's income decile; dotted lines are $95 \%$ confidence intervals. Red solid lines represent the same for white sons. Standard errors generated by bootstrap method following Corak, Lindquist, and Mazumder (2014). Bootstrapping based on 50 draws of 50 father-son pairs within an income score rank decile. Therefore, plots are limited to fathers' income score rank deciles with greater than 50 observations.

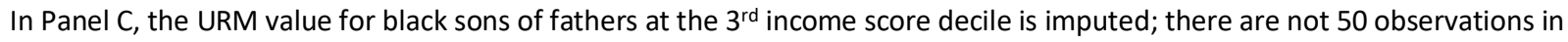
that bucket. 
FIGURE 3: AVERAGE SON'S INCOME SCORE RANK BY FATHER'S INCOME SCORE RANK

PANEL A: 1900 COHORT

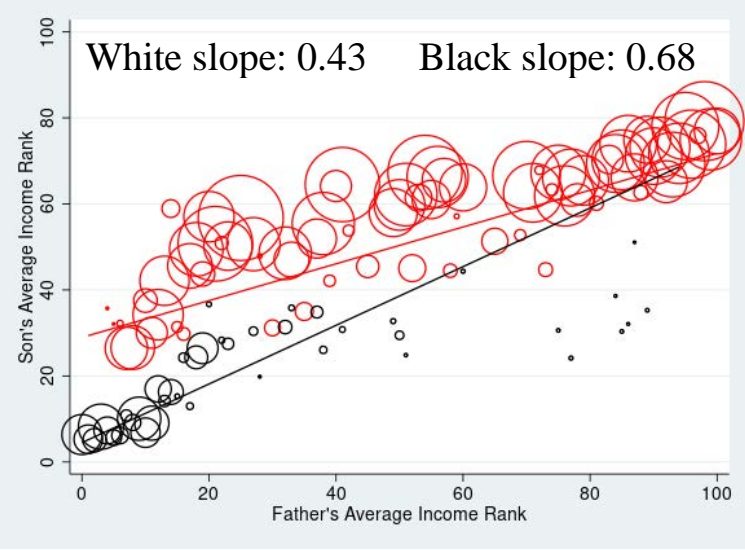

PANEL C: 1962 COHORT

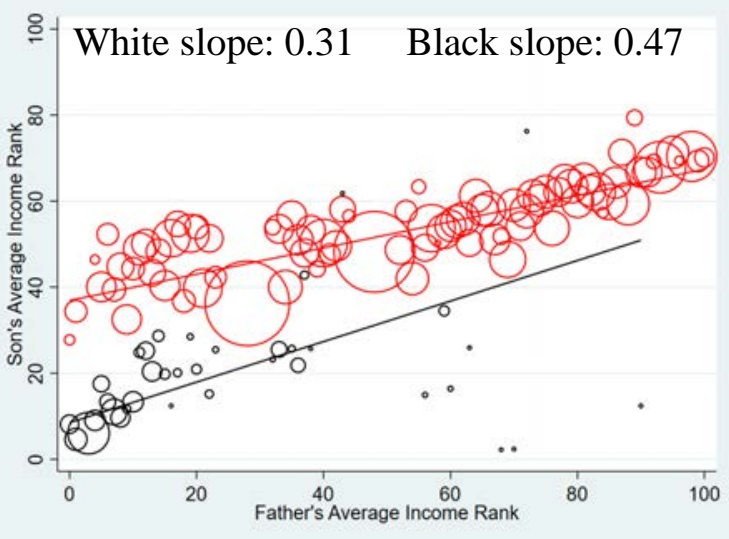

PANEL E: 1990 COHORT

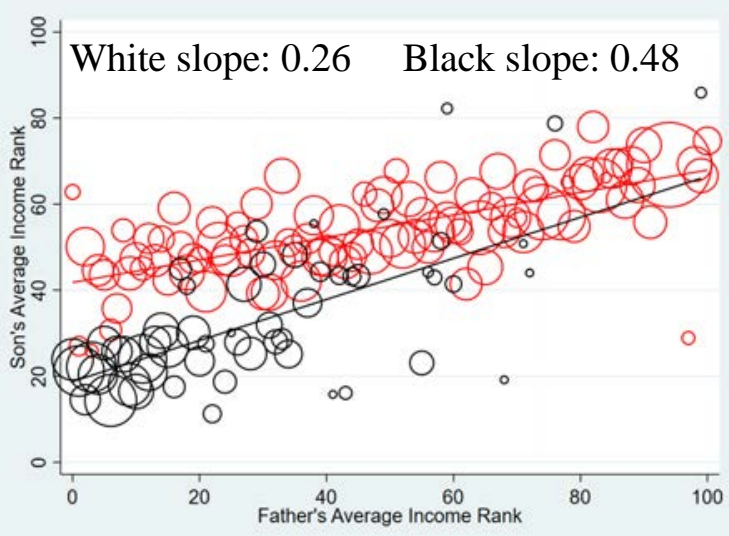

PANEL B: 1930 COHORT

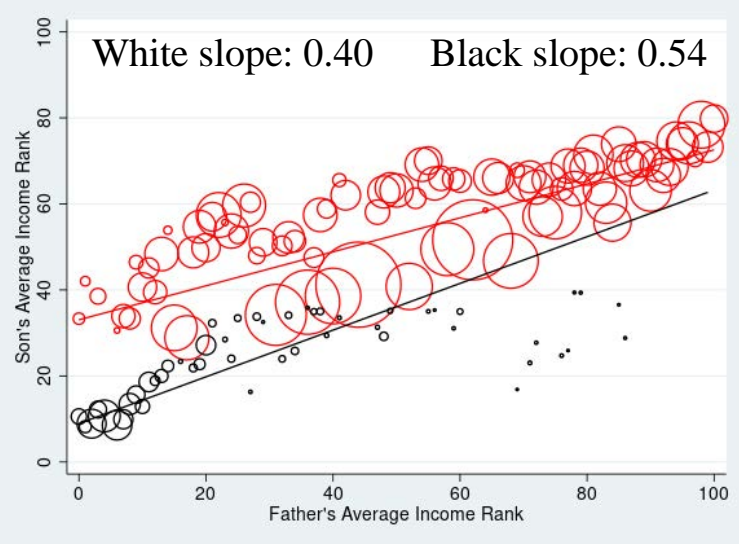

PANEL D: 1973 COHORT

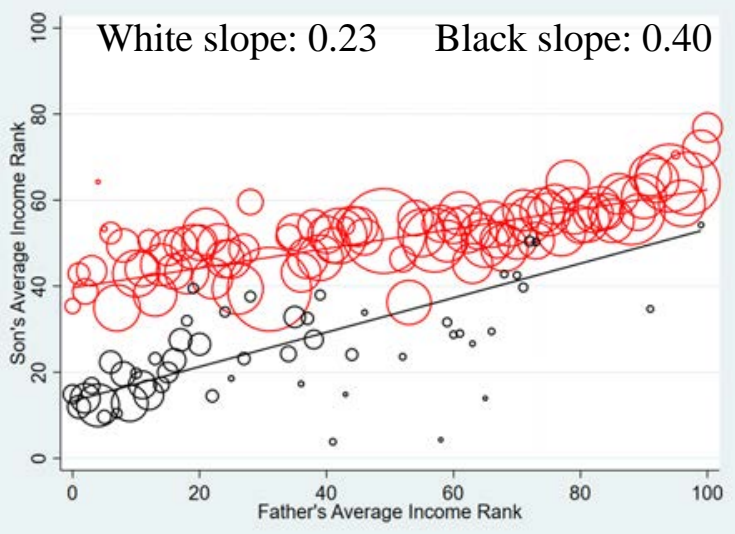

PANEL F: 2000 COHORT

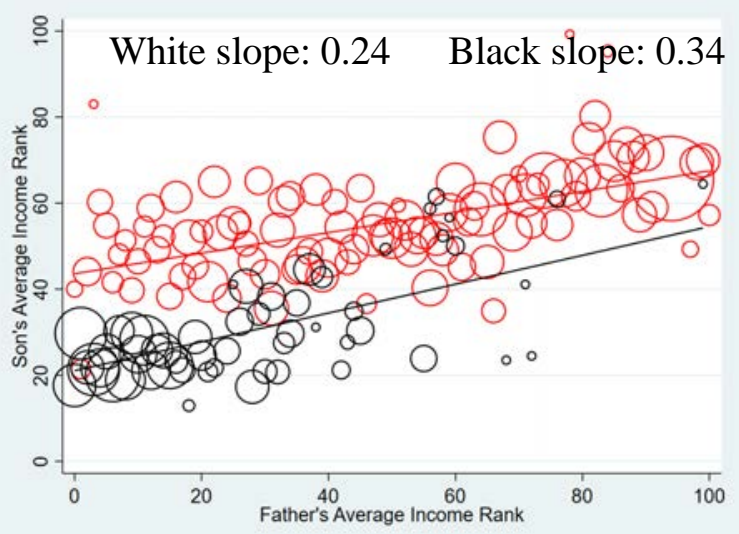

Notes: Black circles represent black parents and sons; red circles reflect white parents and sons. Average values of sons' income ranks for each fathers' income rank (rounded to the nearest unit) are plotted. All circles weighted by number of fathers at that income rank. Linear lines of best fit are for the underlying data, equivalent to the plotted data points (which represent average sons' outcome for each value of fathers' rank) with weights. 
FIGURE 4: COUNTERFACTUAL KERNEL DENSITY PLOTS FOR BLACK SONS INCOME SCORE RANKS UNDER WHITE SONS' TRANSITION RATES

PANEL A: 1900 COHORT

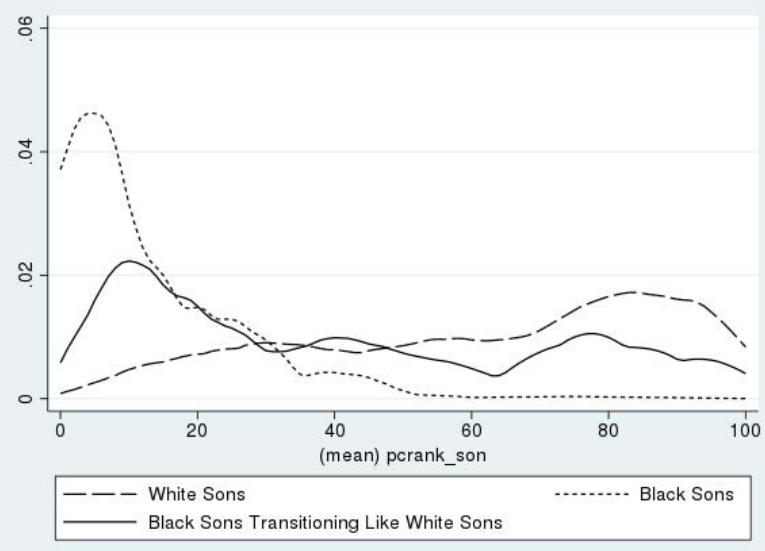

PANEL C: 1962 COHORT

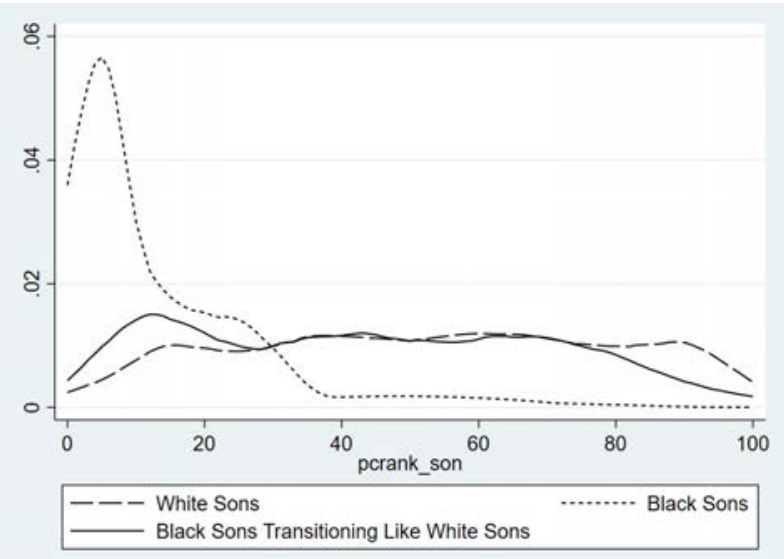

PANEL B: 1930 COHORT

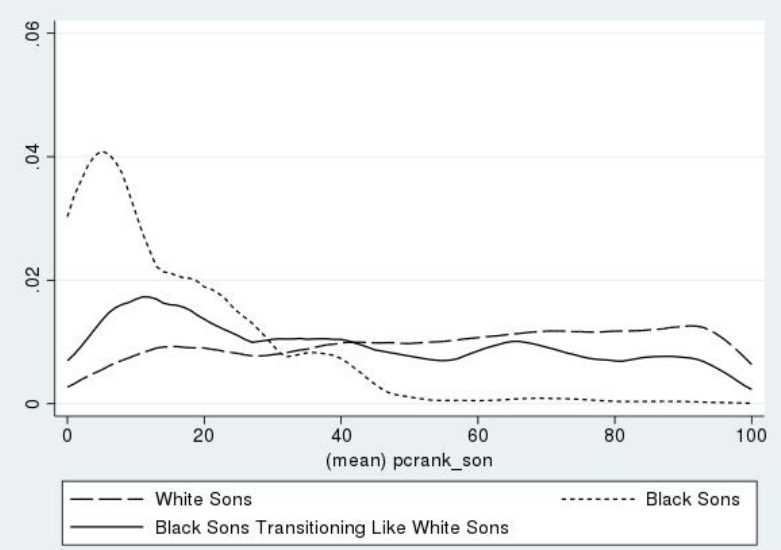

PANEL D: 1973 COHORT

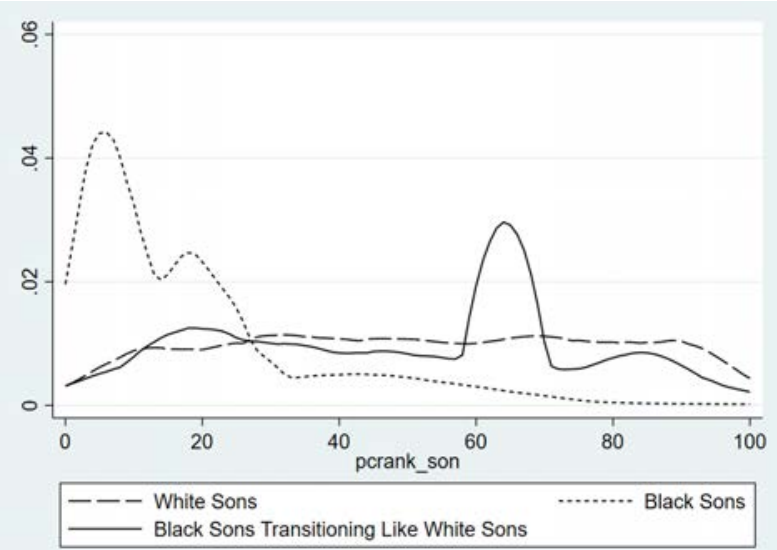

PANEL E: 1990 COHORT

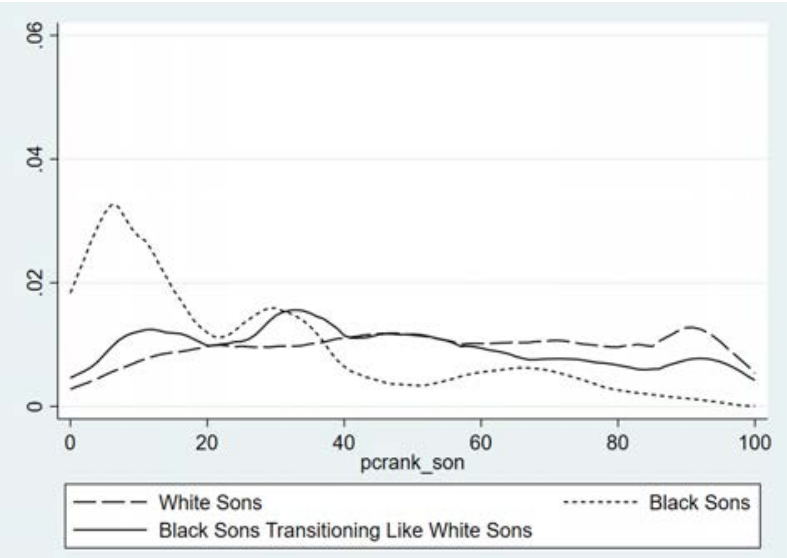

Notes: Long dashes represent the transition patterns of white sons and short dashes represent transition patterns of black sons. Solid lines reflect predicted black sons' outcomes based on actual black fathers' income ranks and white transition probabilities. 
FIGURE 5: OCCUPATIONAL STATUS OF SONS UNDER COUNTERFACTUAL TRANSITIONS
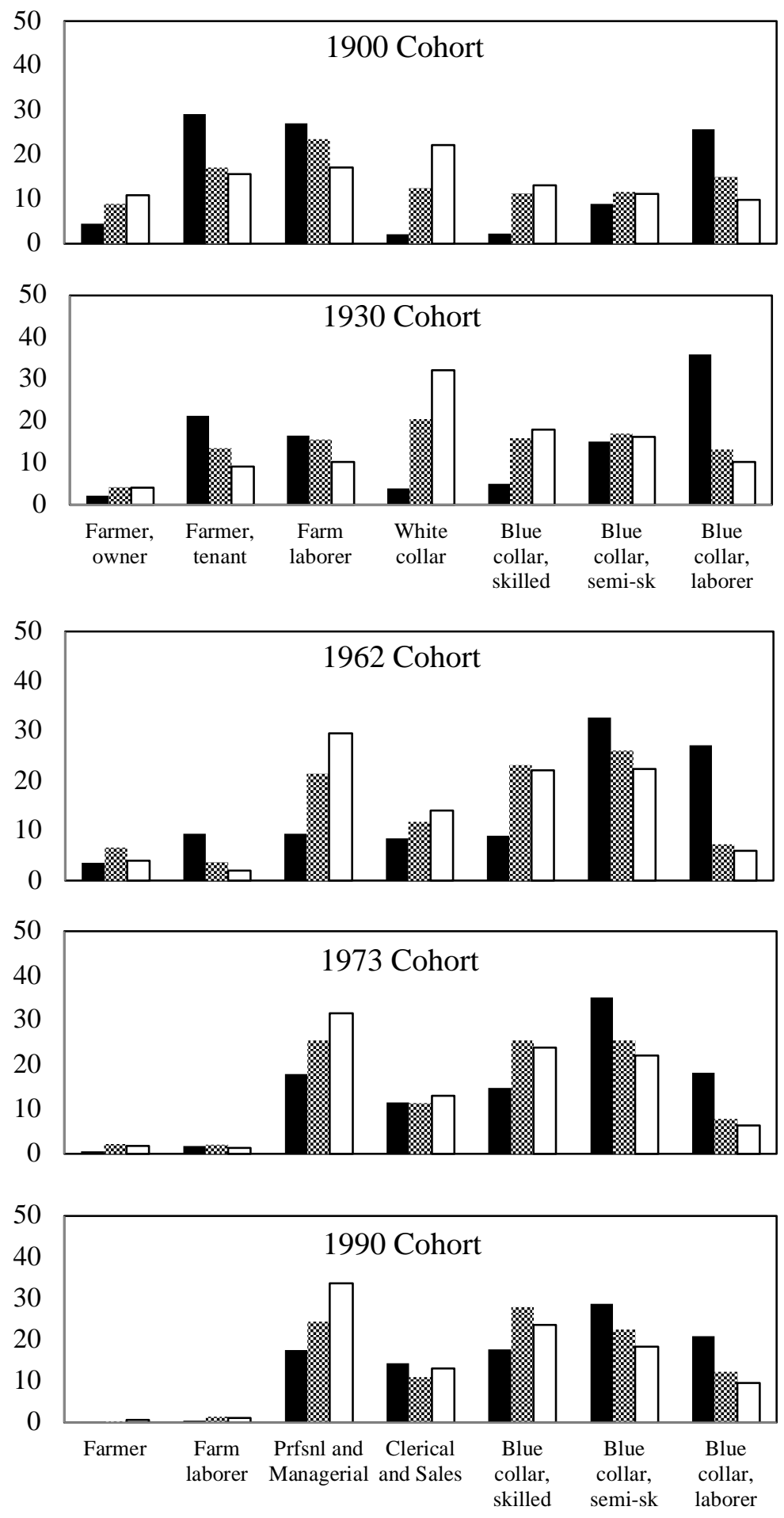

- Black $\approx$ Black with White Transitions $\square$ White

Notes: White bars reflect actual occupation distributions of white sons. Black bars reflect actual distributions of black sons. Gray hatched bars reflect the distributions of black sons keeping the occupation distribution of black fathers fixed, but invoking white father-son occupation transitions. 